\title{
Preliminary Insight of Pyrrolylated-Chalcones as New Anti-Methicillin-Resistant Staphylococcus aureus (Anti-MRSA) Agents
}

\author{
Mohanapriya Gunasekharan ${ }^{1,+}$, Tae-Ik Choi ${ }^{2,+}$, Yaya Rukayadi ${ }^{3,4} \oplus$, Muhammad Alif Mohammad Latif ${ }^{5}$, \\ Thiruventhan Karunakaran ${ }^{6}\left(\mathbb{D}\right.$, Siti Munirah Mohd Faudzi ${ }^{1,3, *}$ and Cheol-Hee Kim ${ }^{2, *(D)}$ \\ 1 Department of Chemistry, Faculty of Science, Universiti Putra Malaysia, Serdang 43400, Selangor, Malaysia; \\ mohanapriyagunasekharan@gmail.com \\ 2 Department of Biology, Chungnam National University, 99 Daehak-ro, Yuseong-gu, Daejeon 34134, Korea; \\ c860523@naver.com \\ 3 Natural Medicines and Product Research Laboratory, Institute of Bioscience, Universiti Putra Malaysia, \\ Serdang 43400, Selangor, Malaysia; yaya_rukayadi@upm.edu.my \\ 4 Department of Food Science, Faculty of Food Science and Technology, Universiti Putra Malaysia, \\ Serdang 43400, Selangor, Malaysia \\ 5 Centre of Foundation Studies for Agricultural Science, Universiti Putra Malaysia, \\ Serdang 43400, Selangor, Malaysia; aliflatif@upm.edu.my \\ check for \\ updates \\ Citation: Gunasekharan, M.; Choi, \\ 6 Centre for Drug Research, Universiti Sains Malaysia, Gelugor 11800, Pulau Pinang, Malaysia; \\ thiruventhan@usm.my \\ * Correspondence: sitimunirah@upm.edu.my (S.M.M.F.); zebrakim@cnu.ac.kr (C.-H.K.) \\ + These authors contributed equally to this work.
}

T.-I.; Rukayadi, Y.; Mohammad Latif, M.A.; Karunakaran, T.; Mohd Faudzi, S.M.; Kim, C.-H. Preliminary Insight of Pyrrolylated-Chalcones as New Anti-Methicillin-Resistant Staphylococcus aureus (Anti-MRSA) Agents. Molecules 2021, 26, 5314. https://doi.org/10.3390/ molecules26175314

Academic Editors:

Constantinos Athanassopoulos and Carlo Siciliano

Received: 28 July 2021

Accepted: 28 August 2021

Published: 1 September 2021

Publisher's Note: MDPI stays neutral with regard to jurisdictional claims in published maps and institutional affiliations.

Copyright: (c) 2021 by the authors. Licensee MDPI, Basel, Switzerland. This article is an open access article distributed under the terms and conditions of the Creative Commons Attribution (CC BY) license (https:// creativecommons.org/licenses/by/ $4.0 /)$.
Abstract: Bacterial infections are regarded as one of the leading causes of fatal morbidity and death in patients infected with diseases. The ability of microorganisms, particularly methicillin-resistant Staphylococcus aureus (MRSA), to develop resistance to current drugs has evoked the need for a continuous search for new drugs with better efficacies. Hence, a series of non-PAINS associated pyrrolylated-chalcones (1-15) were synthesized and evaluated for their potency against MRSA. The hydroxyl-containing compounds $(\mathbf{8}, \mathbf{9}$, and 10) showed the most significant anti-MRSA efficiency, with the MIC and MBC values ranging from 0.08 to $0.70 \mathrm{mg} / \mathrm{mL}$ and 0.16 to $1.88 \mathrm{mg} / \mathrm{mL}$, respectively. The time-kill curve and SEM analyses exhibited bacterial cell death within four hours after exposure to 9 , suggesting its bactericidal properties. Furthermore, the docking simulation between 9 and penicillin-binding protein 2a (PBP2a, PDB ID: 6Q9N) suggests a relatively similar bonding interaction to the standard drug with a binding affinity score of $-7.0 \mathrm{kcal} / \mathrm{mol}$. Moreover, the zebrafish model showed no toxic effects in the normal embryonic development, blood vessel formation, and apoptosis when exposed to up to $40 \mu \mathrm{M}$ of compound 9. The overall results suggest that the pyrrolylatedchalcones may be considered as a potential inhibitor in the design of new anti-MRSA agents.

Keywords: synthesis; pyrrolylated-chalcones; anti-MRSA; molecular docking; zebrafish toxicity

\section{Introduction}

Bacterial infections are one of the significant threats to global health, mainly owing to the resistance of microorganisms towards antibiotics [1]. According to the Centre for Disease Control and Prevention (CDC) in the year 2017, more than 2 million diseases and 23,000 deaths occur annually due to antibiotic resistance in the United States. In the past two decades, the development of new antimicrobials for the treatment of Gram-positive bacterial infections has become a necessity [2]. Staphylococcus aureus is a Gram-positive bacterium that is found on the human skin and can invade the bone joints, respiratory system, and endovascular tissues through the bloodstream [3]. Patients with chronic diseases, i.e., adolescents, elder people, and patients undergoing treatment have a higher tendency to be infected by methicillin-resistant S. aureus (MRSA). In 1950, methicillin was 
found to be effective against S. aureus-related infections [4]. Unfortunately, by 1961, S. aureus was found to be resistant to methicillin. Since then, the number of hospital-acquired and community-acquired MRSA infections and deaths have increased to a number almost similar to that of the number of AIDS and tuberculosis deaths [5].

Although commercially designed antibiotics that treat bacterial infection-related diseases such as methicillin and vancomycin are widely available, these antibiotics however are gradually losing their efficiency due to the constantly evolving bacterial resistance towards antibiotics. Therefore, the need for developing new antibacterial agents that are effective against new strains of microorganisms has drastically increased worldwide.

Chalcones (1,3-diaryl-2-propenone) are acyclic compounds containing an $\alpha, \beta$-unsaturated carbonyl group appended by two aromatic rings and are commonly synthesized via acidor base-catalyzed Aldol or Claisen-Schmidt condensation reactions in the laboratory [6]. Chalcones and its derivatives have displayed a wide range of biological activities including antibacterial, antifungal, anti-inflammatory, antimalarial, anticancer, antiviral, anti-tubercular, anti-hyperglycemic [6], and antioxidant activities [7]. Some studies have also reported on chalcones with potential antimicrobial properties against fungi and bacteria, and even chalcones that are resistant to bacteria [8]. These activities have rendered chalcones as potential compounds for the development of new anti-MRSA agents.

The recent discovery of chalcones that possess high anti-infective potentials and the therapeutic importance of nitrogen-containing marketed antibiotics, has led to the designation of a new chalconoid derivative, the pyrrolylated-chalcone (Figure 1), whereby the pyrrole moiety is incorporated into the chalcone scaffold. This fusion is hypothesized to further improve the binding interactions with the active site of MRSA, thus enhancing the targeted anti-MRSA activity.<smiles>[R]c1ccc(/C=C/C(=O)c2ccc[nH]2)cc1</smiles>

Figure 1. Molecular structure of chalcone (1,3-diaryl-2-propenone).

As a continuation of our endeavors towards the exploration of the therapeutic potential of pyrrolylated-chalcones as new anti-MRSA hit-candidates, we herein evaluate the anti-MRSA properties of the pyrrolylated-chalcones (1-15) using in vitro disc diffusion, MIC, MBC, time-kill, and SEM analyses. The active molecules were then analyzed using molecular docking studies to further understand the binding mode and affinity of the compounds that exhibit the most potent and prominent MRSA inhibition. In addition, the most active compound 9 , was preliminarily profiled for in vivo toxicities using the zebrafish animal model.

\section{Results and Discussion}

\subsection{Chemistry}

In this present study, a series of non-associated pan-assay interference compounds (PAINS) (see Supplementary Materials), the pyrrolylated-chalcones, including new analogues 5 and 11-15 were synthesized via Claisen-Schmidt condensation by reacting 2-acetylpyrrole with the appropriate fluoro-, nitro-, and hydroxyl-containing benzaldehydes in ethanolic sodium hydroxide for $24 \mathrm{~h}$ at room temperature (Scheme 1) [9]. All the synthesized compounds were purified by gravitational column chromatography and recrystallization techniques, followed by structural elucidation via spectroscopic analyses, including ${ }^{1} \mathrm{H}-,{ }^{13} \mathrm{C}-$, and ${ }^{19} \mathrm{~F}-\mathrm{NMR}$, Fourier transform infra-red (FT-IR), and direct infusion-mass spectrometry (DI-MS), as well as high-resolution mass spectrometry (HRMS) for new molecules. The spectroscopic data of the newly synthesized analogues ( 5 and 11-15), general physical properties (Table S1), as well as the predicted physicochemical and 
drug-likeness properties (Table S2) of the synthesized molecules (1-15) were appended in Supplementary Materials.

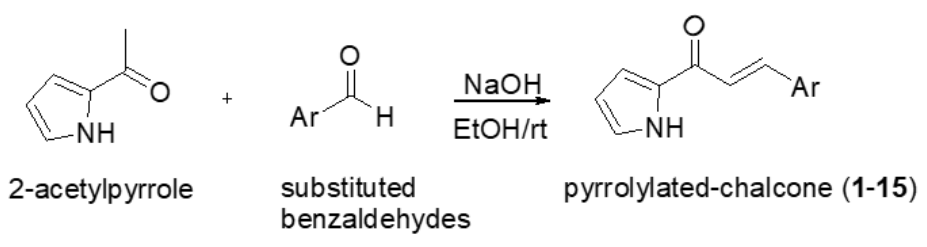

$\operatorname{Ar}=$<smiles>Oc1ccccc1</smiles><smiles>[R]Oc1ccccc1F</smiles><smiles>O=[N+]([O-])c1cccc(S(=O)(=O)[O-])c1</smiles><smiles>Fc1cccc([TlH])c1F</smiles><smiles>O=[N+]([O-])c1ccc([18O])cc1</smiles><smiles>O=P(O)(O)c1ccccc1O</smiles><smiles>[Y6]c1ccc(F)cc1F</smiles><smiles>Fc1cccc([123I])c1</smiles><smiles>[Mg]</smiles><smiles>Fc1ccc(F)cc1</smiles><smiles>Oc1cccc(O)c1</smiles><smiles>Cc1cc(F)ccc1F</smiles><smiles>Fc1ccc([AlH2])cc1F</smiles>

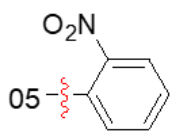<smiles>Oc1ccc([18OH])cc1</smiles><smiles>Fc1cc(F)cc(S)c1</smiles>

Scheme 1. General synthetic preparation for pyrrolylated-chalcone analogues (1-15).

Compounds 1-15 exhibited the peaks of $\alpha$ - and $\beta$ - methine moieties $\left(\delta_{\mathrm{H}} 7.28-12.30 \mathrm{ppm}\right.$ and 7.67-12.30 ppm; $\delta_{C} 119.5-128.8 \mathrm{ppm}$ and $131.1-141.1 \mathrm{ppm}$ ) with $J$ values of $15.7-16.1 \mathrm{~Hz}$, indicated the trans configuration for the conjugated olefinic system. Meanwhile, the pyrrole and phenolic proton(s) were spotted in the range of $\delta_{\mathrm{H}} 6.17-7.64 \mathrm{ppm}$ and $6.93-8.67 \mathrm{ppm}$.

The presence of electron-withdrawing groups (-F and $\left.-\mathrm{NO}_{2}\right)$, particularly the difluorosubstituted benzene gave a higher product yield, ranging from 65.4 to $90.2 \%$. On the other hand, the hydroxylated compounds (electron-donating group) recorded lower yields $(<12.9 \%)$. Taking this into account, we concluded that the shortening of the $\mathrm{C}=\mathrm{O}$ bond due to the inductive effect exerted by the electron-withdrawing functionalities greatly improves the yield of the end products [10].

It is important to highlight that though many analogues of pyrrolylated-chalcones have been previously synthesized for various bioactivities [9,11-14], we would like to explore further the therapeutic uses of the synthesized chalcones particularly as anti-MRSA agents in this present study. Little has been reported on the in-depth anti-MRSA potential of pyrrolylated-chalcones thus far.

\subsection{In Vitro Anti-MRSA Activity}

Following that, the prospective antibacterial activity of the synthesized compounds against the standard ATCC 700699 and three clinical isolates (172918, 180620, and 180865) of $S$. aureus bacteria strains was first determined through the disc diffusion assay (DDA). Compounds with significant bacterial inhibition were then further tested via the minimum inhibitory concentration (MIC) and minimum bactericidal concentration (MBC) assays to confirm their bioactivity. The anti-MRSA efficiency results are displayed in Table 1. 
Table 1. In vitro anti-MRSA activity evaluation of pyrrolylated-chalcone analogues (1-15) against standard and clinical Staphylococcus aureus strains.

\begin{tabular}{|c|c|c|c|c|c|c|c|c|c|c|c|c|}
\hline & \multicolumn{3}{|c|}{$\begin{array}{c}\text { MRSA ATCC } \\
\text { (700699) }\end{array}$} & \multicolumn{3}{|c|}{$\begin{array}{c}\text { Clinical MRSA } \\
(\mathbf{1 7 2 9 1 8 )}\end{array}$} & \multicolumn{3}{|c|}{$\begin{array}{c}\text { Clinical MRSA } \\
\quad(180620)\end{array}$} & \multicolumn{3}{|c|}{$\begin{array}{c}\text { Clinical MRSA } \\
\text { (180865) }\end{array}$} \\
\hline & $\begin{array}{c}\text { Zone of } \\
\text { Inhibition } \\
(\mathrm{mm})\end{array}$ & $\begin{array}{c}\mathrm{MIC} \\
(\mathrm{mg} / \mathrm{mL})\end{array}$ & $\begin{array}{c}\mathrm{MBC} \\
(\mathrm{mg} / \mathrm{mL})\end{array}$ & $\begin{array}{c}\text { Zone of } \\
\text { Inhibition } \\
(\mathrm{mm})\end{array}$ & $\underset{(\mathrm{mg} / \mathrm{mL})}{\mathrm{MIC}}$ & $\begin{array}{c}\mathrm{MBC} \\
(\mathrm{mg} / \mathrm{mL})\end{array}$ & $\begin{array}{c}\text { Zone of } \\
\text { Inhibition } \\
(\mathrm{mm})\end{array}$ & $\begin{array}{c}\text { MIC } \\
(\mathrm{mg} / \mathrm{mL})\end{array}$ & $\begin{array}{c}\text { MBC } \\
(\mathrm{mg} / \mathrm{mL})\end{array}$ & $\begin{array}{c}\text { Zone of } \\
\text { Inhibition } \\
(\mathrm{mm})\end{array}$ & $\begin{array}{c}\mathrm{MIC} \\
(\mathrm{mg} / \mathrm{mL})\end{array}$ & $\begin{array}{c}\mathrm{MBC} \\
(\mathrm{mg} / \mathrm{mL})\end{array}$ \\
\hline 1 & n.a & - & - & n.a & - & - & n.a & - & - & n.a & - & - \\
\hline 2 & n.a & - & - & n.a & - & - & n.a & - & - & n.a & - & - \\
\hline 3 & n.a & - & - & n.a & - & - & n.a & - & - & n.a & - & - \\
\hline 4 & n.a & - & - & n.a & - & - & n.a & - & - & n.a & - & - \\
\hline 5 & n.a & - & - & n.a & - & - & n.a & - & - & n.a & - & - \\
\hline 6 & n.a & - & - & n.a & - & - & n.a & - & - & n.a & - & - \\
\hline 7 & n.a & - & - & n.a & - & - & n.a & - & - & n.a & - & - \\
\hline 8 & $9.00 \pm 1.4$ & $0.23 \pm 0.1$ & $0.31 \pm 0.0$ & $8.50 \pm 0.7$ & $0.08 \pm 0.0$ & $0.16 \pm 0.0$ & $8.50 \pm 0.7$ & $\#$ & $\#$ & $8.00 \pm 0.0$ & $0.70 \pm 0.8$ & $0.94 \pm 0.4$ \\
\hline 9 & $8.00 \pm 1.4$ & $0.23 \pm 0.1$ & $0.47 \pm 0.2$ & $8.50 \pm 0.7$ & $0.70 \pm 0.8$ & $1.41 \pm 1.6$ & $9.00 \pm 0.0$ & $\#$ & $\#$ & $9.00 \pm 0.0$ & $0.31 \pm 0.0$ & $0.63 \pm 0.0$ \\
\hline 10 & $9.00 \pm 0.0$ & $0.47 \pm 0.2$ & $1.56 \pm 1.3$ & $8.50 \pm 0.7$ & $0.31 \pm 0.0$ & $1.88 \pm 0.9$ & $10.00 \pm 0.0$ & $\#$ & $\#$ & $7.50 \pm 0.0$ & $0.23 \pm 0.1$ & $1.88 \pm 0.9$ \\
\hline 11 & n.a & - & - & n.a & - & - & n.a & - & - & n.a & - & - \\
\hline 12 & n.a & - & - & n.a & - & - & n.a & - & - & n.a & - & - \\
\hline 13 & n.a & - & - & n.a & - & - & n.a & - & - & n.a & - & - \\
\hline $\mathrm{CHX}^{*}$ & $14.00 \pm 1.4$ & $0.03 \pm 0.0$ & $0.20 \pm 0.2$ & $14.50 \pm 0.7$ & $0.03 \pm 0.0$ & $0.07 \pm 0.1$ & $15.00 \pm 0.0$ & - & - & $14.50 \pm 0.7$ & $0.12 \pm 0.1$ & $0.23 \pm 0.1$ \\
\hline
\end{tabular}

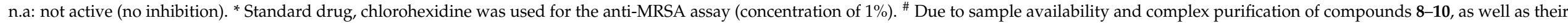

slightly lower diameter inhibition compared to other MRSA strains, therefore, these molecules were not tested against clinical bacteria 180620 strain for MIC and MBC analyses. 


\subsubsection{Disc Diffusion Assay}

Based on the preliminary DDA screening results, the hydroxyl-containing compounds 8, 9, and 10 showed the most significant anti-MRSA activity with a recorded inhibition zone ranging between $7.50-10.00 \mathrm{~mm}$ compared to the standard chlorhexidine (CHX) $(14.00-15.00 \mathrm{~mm})$. Although compounds 8, 9, and $\mathbf{1 0}$ exhibited lower anti-MRSA potential than the standard drug, CHX, we decided that it was still beneficial to proceed with the determination of their MIC and MBC values against the tested standard and clinical $S$. aureus strains. Meanwhile, the other molecules which compose the nitro- and fluorogroups (compounds 1-7 and 11-15) showed weak bacterial inhibition, signifying their poor antibacterial efficacy.

Owing to its strong bactericidal power and stability, the antiseptic CHX was used as the standard control in this experiment in comparison to other common anti-MRSA drugs including vancomycin, ampicillin, and streptomycin. Moreover, $\mathrm{CHX}$ is frequently used in hospitals to reduce MRSA infections, particularly for bathing patients in intensive care units and preventing the spread of hospital-acquired diseases [15] and thereby further justify its practical utilization.

The structure-activity relationship (SAR) revealed that the hydroxyl group, regardless of their position (ortho/meta/para) on the phenyl ring, was responsible for the improved MRSA inhibitory activity. The tendency of the -OH moiety to form a strong hydrogen bond to the important amino acid residues on the active sites of the receptor might have contributed to their significant antibacterial property. This result is in accordance with Stompor and Zarowska (2016) and Xu et al. (2019), which stated that the free hydroxyl group in position(s) ortho and/or para appears to be significant to anti-MRSA efficacy on its own, or in combination with antibiotics $[16,17]$. Inversely, the inhibition of $S$. aureus was found to be diminished in the electron-withdrawing substituted analogues, following the trend concluded by Kozlowska et al. (2019), Stompor and Zarowska (2016) and Ma et al. (2011), which suggested the lack of a hydroxyl group and the substitution of the halogen $(\mathrm{Cl}-, \mathrm{Br}-)$ and nitro moieties into the chemical scaffold of interest may have resulted in the inactivation of the compounds with regards to $S$. aureus $[16,18,19]$. In addition, the mono- and new difluorinated chalcones (2-4 and 11-15) were designed and synthesized with the aim to increase the number of $\mathrm{H}$-bond to the amino acid residues of targeted bacterial sites and thus improve the bioactivity, and to enhance the pharmacokinetic and pharmacodynamic (PK/PD) properties including the membrane permeability, solubility, metabolic pathways of the analogues [20]. However, such predicted improved properties were unable to significantly increase their targeted anti-MRSA efficacy, reflecting the importance of the electron-donating hydroxyl group as the key functional fragments that are responsible for the MRSA inhibition.

\subsubsection{Determination of Minimum Inhibitory Concentration (MIC) and Minimum Bactericidal Concentration (MBC)}

The anti-MRSA activities of the most active molecules (compounds 8, 9, and 10) were then further validated by determining their MIC and MBC values. Based on Table 1, compound 8 exhibited the most significant MIC and MBC values, whereby it only required a low concentration of $0.08 \pm 0.0 \mathrm{mg} / \mathrm{mL}$ to inhibit the growth of the clinical bacteria 172918 strain and a slightly lower concentration $(0.16 \pm 0.0 \mathrm{mg} / \mathrm{mL})$ to express either bactericidal or bacteriostatic effect. It is noteworthy to mention that the MIC and MBC results provide limited information on the kinetics of the antimicrobial action. Hence, the time-killing assay was performed to find a correlation between the rate of bactericidal activity with the incubation time and concentration of the antimicrobial agent [21]. On a separate note, though the recorded MIC and MBC values do not appear to be promising by current clinical standards, it should be highlighted that these preliminary results could be useful for subsequent hit-to-lead optimization to further improve the potency and bacterial resistance of the new compounds. Lastly, due to a shortage of sample availability of compounds 8-10 and their slightly lower diameter inhibition compared to other MRSA 
strains, no further MIC and MBC analyses against clinical bacteria 180620 strain were conducted.

\subsubsection{Determination of Time-Kill Curve}

The most suitable method to determine the bactericidal or bacteriostatic mechanism of action is through the time-kill curve analysis. It is a reliable tool that is utilized to obtain information on the dynamic interaction between an antimicrobial agent and microbial strain [22]. The time-kill curve may also reveal the relationship between concentration and time in eliciting an antimicrobial effect. The antibacterial activity was measured as a reduction of the total count of $\mathrm{CFU} / \mathrm{mL}$ by $99.9 \%\left(\geq 3 \log _{10}\right)$ compared to the original bacterial inoculum [23]. The antimicrobial agent was viewed as bacteriostatic at the lowest concentration that diminishes the original inoculum size $0-3 \log _{10} \mathrm{CFU} / \mathrm{mL}$, and bactericidal if the inoculum size was decreased by $>3 \log _{10} \mathrm{CFU} / \mathrm{mL}[24,25]$.

The tested concentrations of compounds $8, \mathbf{9}$, and $\mathbf{1 0}$ are $0 \times \mathrm{MIC}, 1 \times \mathrm{MIC}, 2 \times \mathrm{MIC}$, and $4 \times$ MIC, as listed in Table 2 . The selected concentrations used are equal to the MIC, twice the MIC, and four times the MIC values of the tested compound. Plots of the time-kill curve for MRSA ATCC 700699 and 172918 of compounds 8, 9, and $\mathbf{1 0}$ at varying concentrations $(0 \times$ MIC to $4 \times$ MIC) were constructed to determine the correlation between MIC and the bactericidal activity, respectively, in which each plot displayed the endpoint after four hours of incubation.

Table 2. Concentrations of compounds 8, 9, and 10 used $(0 \times \mathrm{MIC}, 1 \times \mathrm{MIC}, 2 \times \mathrm{MIC}$ and $4 \times \mathrm{MIC})$ for the time-kill test.

\begin{tabular}{cccccc}
\hline Compound & S. aureus Strain & $\begin{array}{c}\mathbf{0} \times \mathbf{M I C} \\
(\mathbf{m g} / \mathbf{m L})\end{array}$ & $\begin{array}{c}\mathbf{1} \times \mathbf{M I C} * \\
(\mathbf{m g} / \mathbf{m L})\end{array}$ & $\begin{array}{c}\mathbf{2} \times \mathbf{M I C} \\
(\mathbf{m g} / \mathbf{m L})\end{array}$ & $\begin{array}{c}\mathbf{4} \times \mathbf{M I C} \\
(\mathbf{m g} / \mathbf{m L})\end{array}$ \\
\hline \multirow{2}{*}{$\mathbf{8}$} & MRSA ATCC 700699 & 0 & 0.156 & 0.313 & 0.625 \\
& Clinical MRSA 172918 & 0 & 0.078 & 0.156 & 0.313 \\
\hline \multirow{2}{*}{$\mathbf{9}$} & MRSA ATCC 700699 & 0 & 0.156 & 0.313 & 0.625 \\
& Clinical MRSA 172918 & 0 & 0.156 & 0.313 & 0.625 \\
\hline \multirow{2}{*}{$\mathbf{1 0}$} & MRSA ATCC 700699 & 0 & 0.313 & 0.625 & 1.250 \\
& Clinical MRSA 172918 & 0 & 0.313 & 0.625 & 1.250 \\
\hline
\end{tabular}

* The MIC values used were obtained through the MIC assay and are tabulated in Table 1.

The time-kill kinetic profiles of compounds 8, 9, and 10 (Figure 2A-C) displayed an abrupt decrease in the number of $S$. aureus ATCC 700699 colonies, in which a $3 \log _{10}$ reduction in viable cell count relative to the initial inoculum at $1 \times$ MIC value was observed after four hours' exposure. Therefore, it is suggested that compounds 8, 9, and 10 may act as bactericidal agents based on the results. Furthermore, it was observed that compounds 8, 9, and 10 killed the standard MRSA ATCC and clinical MRSA172918 strains in a concentrationdependent manner (Figure 2A-F).

\subsection{Molecular Docking Studies}

Consequently, the bioactive compounds 8,9 , and $\mathbf{1 0}$ were docked into the active sites of PBP2a (PDB ID: 6Q9N) to elucidate the key molecular interactions that might be responsible for their significant anti-MRSA properties, and the results were compared to the standard drugs, CHX, and quinazoline. Two types of rigid docking procedures, the blind and site-specific, have been performed as tabulated in Table 3. 
(A)

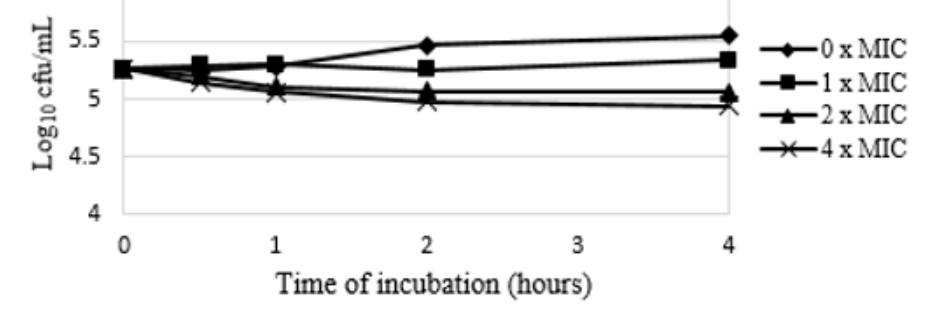

(B)

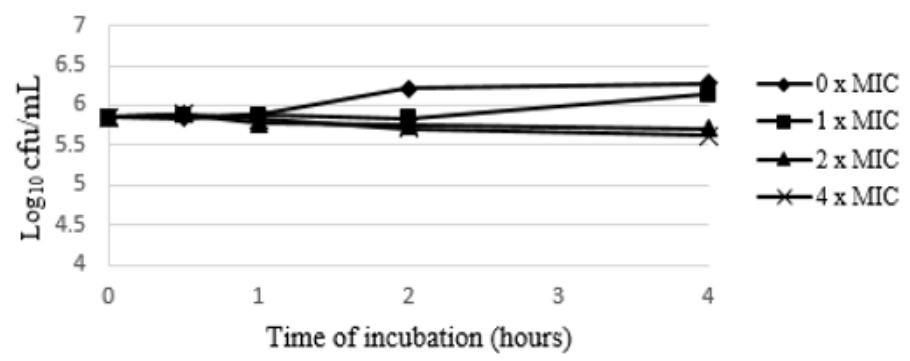

(C)

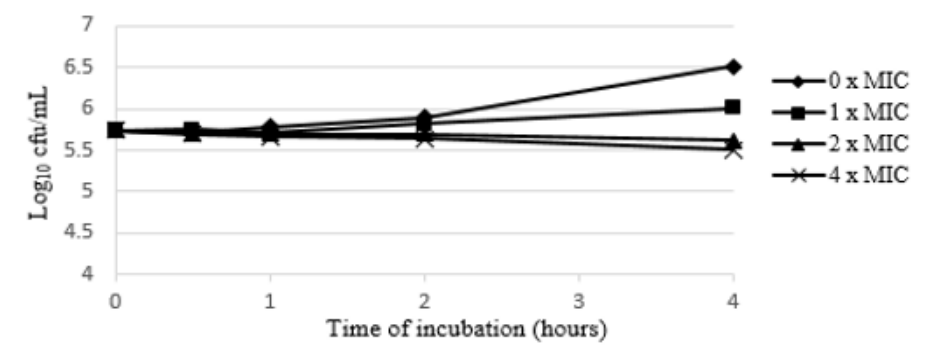

(D) 7

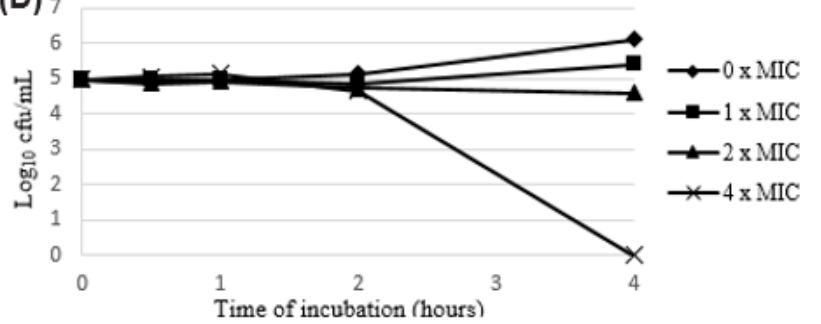

(E) 6

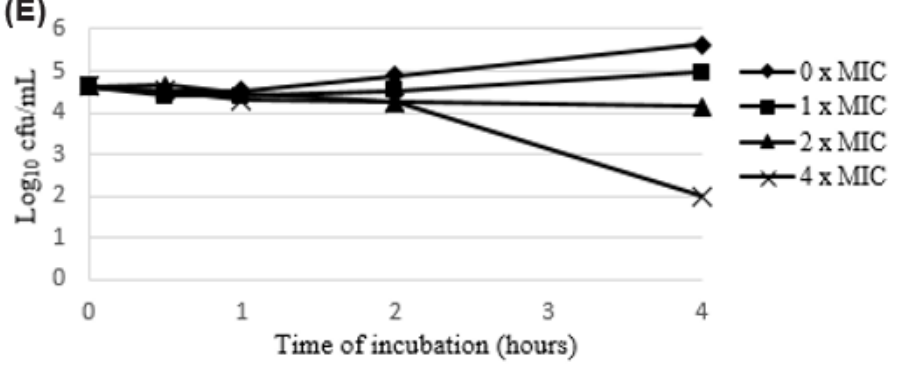

(F)

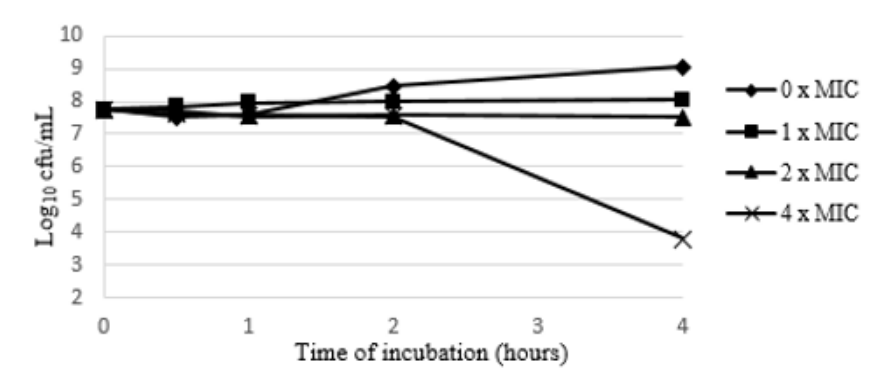

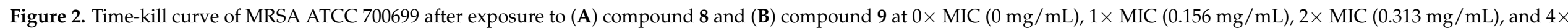

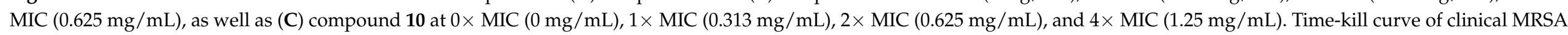

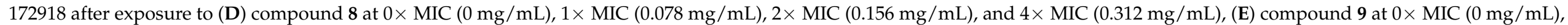

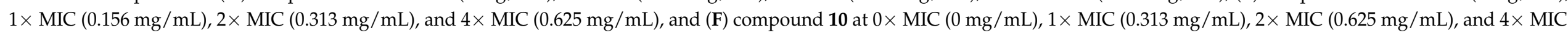
(1.25 mg/mL). 
Table 3. Concentrations of compounds 8, 9, and 10 used $(0 \times \mathrm{MIC}, 1 \times \mathrm{MIC}, 2 \times \mathrm{MIC}$ and $4 \times \mathrm{MIC})$ for the time-kill test.

\begin{tabular}{|c|c|c|c|c|c|}
\hline \multicolumn{6}{|c|}{ Blind Docking } \\
\hline Compound & 8 & 9 & 10 & CHX & Quinazolinone \\
\hline $\begin{array}{l}\text { Binding affinity } \\
(\mathrm{Kcal} / \mathrm{mol})\end{array}$ & -6.9 & -7.0 & -6.7 & -7.0 & -8.8 \\
\hline $\begin{array}{l}\text { Amino acid } \\
\text { residues }\end{array}$ & $\begin{array}{c}\text { Ser } 461 \\
\text { Tyr } 446 \\
\text { Met } 641 \\
\text { Asn } 464 \\
\text { Tyr } 519\end{array}$ & $\begin{array}{c}\text { Tyr } 446 \\
\text { Met } 641 \\
\text { Ser } 403 \\
\text { Asn } 464 \\
\text { Tyr } 519 \\
\text { His } 583\end{array}$ & $\begin{array}{l}\text { Tyr } 366 \\
\text { Gln } 396 \\
\text { His } 251 \\
\text { Lys } 281 \\
\text { Lys } 285 \\
\text { Leu } 286 \\
\text { Pro } 497\end{array}$ & $\begin{array}{c}\text { Gly } 282 \\
\text { Lys } 281 \\
\text { Phe } 498 \\
\text { Asp } 491 \\
\text { Ser } 494 \\
\text { Ile } 492 \\
\text { Leu } 286 \\
\text { Pro } 497\end{array}$ & $\begin{array}{l}\text { Asn } 236 \\
\text { Phe } 211 \\
\text { Thr } 210 \\
\text { Trp } 205 \\
\text { Pro } 213 \\
\text { Glu } 170\end{array}$ \\
\hline \multicolumn{6}{|c|}{ Site-Specific Docking } \\
\hline $\begin{array}{l}\text { Binding affinity } \\
(\mathrm{Kcal} / \mathrm{mol})\end{array}$ & -6.9 & -7.0 & -6.7 & -8.2 & -8.9 \\
\hline $\begin{array}{l}\text { Amino acid } \\
\text { residues }\end{array}$ & $\begin{array}{c}\text { Ala } 642 \\
\text { Tyr } 446 \\
\text { Met } 641 \\
\text { Asn } 464 \\
\text { Tyr } 519\end{array}$ & $\begin{array}{c}\text { Tyr } 446 \\
\text { Met } 641 \\
\text { Asn } 464 \\
\text { Tyr } 519\end{array}$ & $\begin{array}{c}\text { Tyr } 446 \\
\text { Met } 641 \\
\text { Asn } 464 \\
\text { Tyr } 519\end{array}$ & $\begin{array}{c}\text { Lys } 430 \\
\text { Lys } 406 \\
\text { Ser } 462 \\
\text { Asn } 464 \\
\text { Tyr } 519 \\
\text { His } 583\end{array}$ & $\begin{array}{c}\text { Asn } 464 \\
\text { Gln } 521 \\
\text { Tyr } 446 \\
\text { Met } 641 \\
\text { His } 583 \\
\text { Gln } 613\end{array}$ \\
\hline
\end{tabular}

The generated results indicate binding affinities of $-8.8 \mathrm{kcal} / \mathrm{mol}$ and $-8.9 \mathrm{kcal} / \mathrm{mol}$ for the corresponding blind and site-specific docking analyses of quinazolinone allosteric inhibitor, an original ligand in the PBP2a crystals. Through the blind docking experiment, quinazolinone exhibited a similar pose and comparable binding affinity value as previously reported ligands in the same active site of the crystal proteins [26]. These findings, hence, validate the docking parameters utilized in this study.

It is worth noting that compound 9 recorded the highest binding affinity at $-7.0 \mathrm{kcal} / \mathrm{mol}$ among the bioactive hydroxylated analogues. Analogue 9 also showed almost similar interactions as CHX $(-8.2 \mathrm{kcal} / \mathrm{mol})$ with regards to the amino acid residues of the active sites of PBP2a, relative to 8 and 10. Based on the molecular docking analysis (Figure 3), the -NH of pyrrole and carbonyl functionalities of compound 9 form multiple H-bonding with amino acid residues Ser403 and Asn464. Meanwhile, the pyrrole and phenyl moieties were C-H bonded (light green line) with the Tyr519 residue, as well as hydrophobically interacting with the Met641 and Tyr446 residues via $\pi$-sulphur and $\pi-\pi$ stacking, respectively. All the binding interactions involved are tabulated in Table 4.

For the activity comparison, CHX was docked on the same active sites of PBP2a. Overall, CHX shows better affinity compared to compound 9. Dong et al. (2019) suggested that the length of the alkyl chain and the number of guanidino groups on CHX may have contributed to a significant increase in inhibitory efficiency, specifically towards human O-GlcNAcase (hOGA), an enzyme that might be responsible for diabetes, cancer, and Alzheimer's disease [27]. The presence of $\pi$-alkyl interactions could be responsible for the normalizing of the dipole moment of the drug by transferring the charge to its adjacent amino acids. According to the results, strong H-bond interactions (green dashed line) were recorded between the -NH functionality and Asn464, Tyr519, and Ser462 residues. Meanwhile, the $\pi$-alkyl interaction (light purple dashed line) between the chlorine atom and His 583 further strengthens the hydrophobic interaction of the ligand in the receptorbinding pocket. 

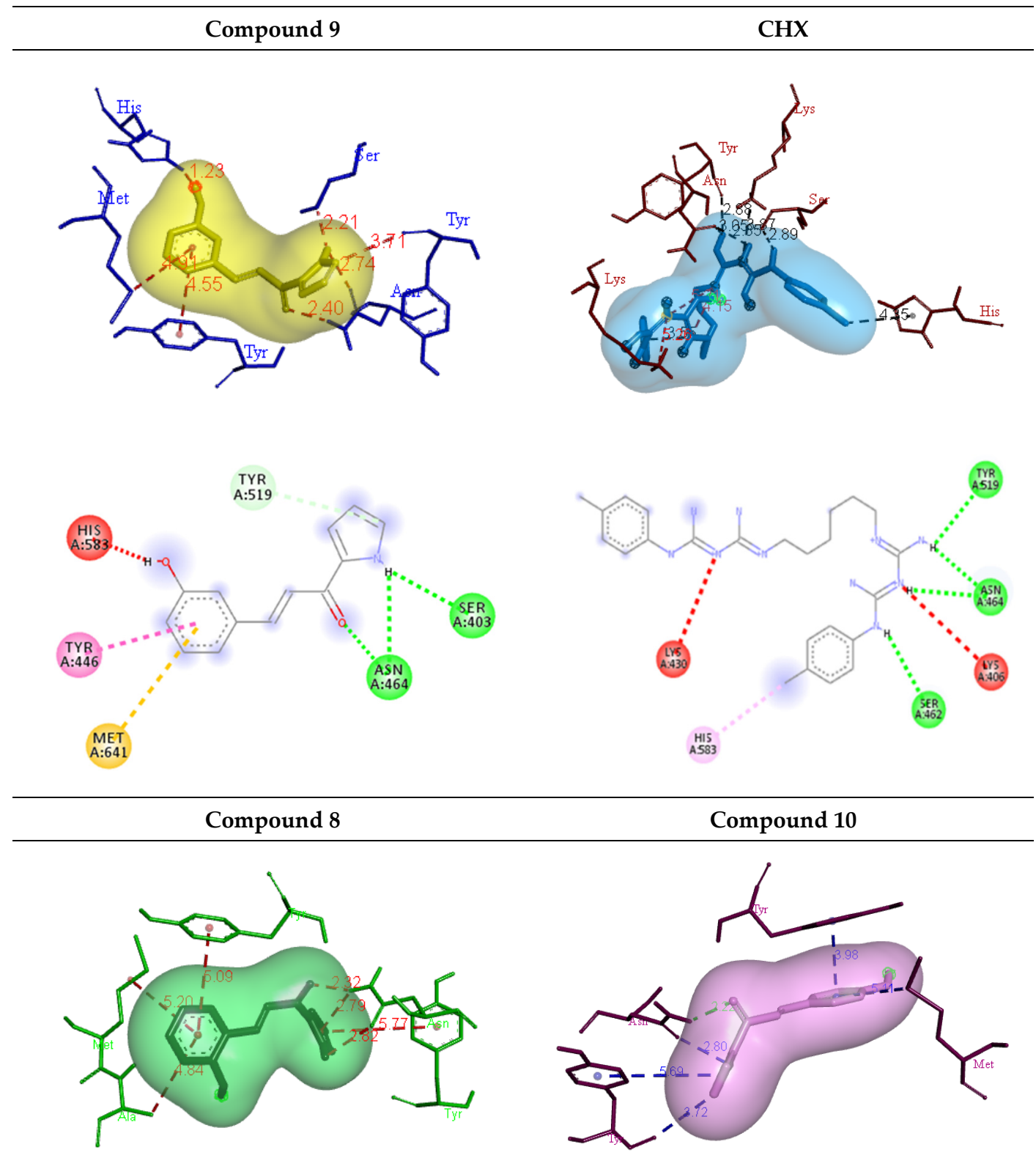

Compound 10
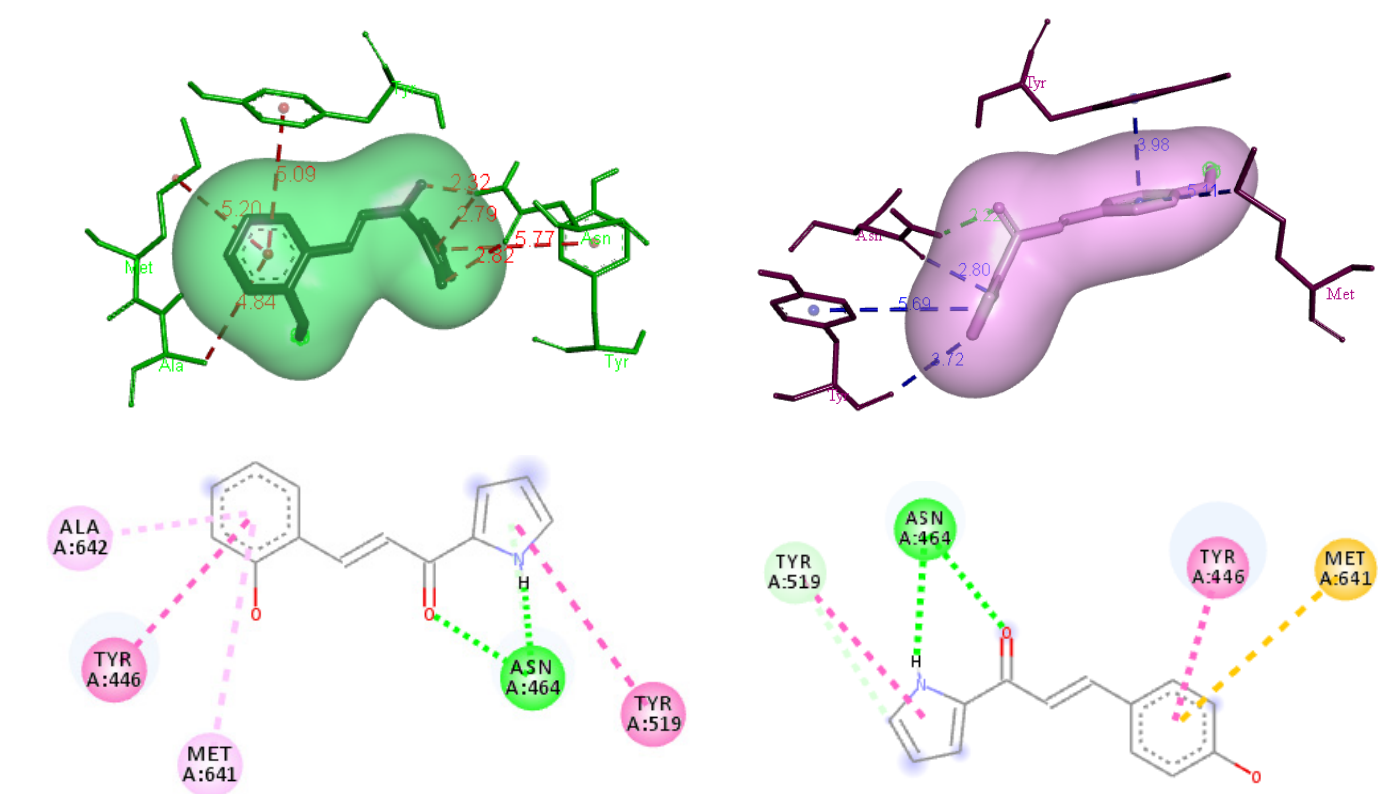

Figure 3. 3D and 2D diagrams of the binding interaction of hydroxylated compounds 8, 9, and $\mathbf{1 0}$ (green line: $\mathrm{H}$ bond; light green line; carbon $\mathrm{H}$ bond/ $\pi$-donor $\mathrm{H}$ bond; red line: donor-donor; yellow line: $\pi$-sulphur; pink line: $\pi-\pi$ stacked $/ \pi-\pi$ T-shaped; light pink line: $\pi$-alkyl) and CHX (green line: H bond; red line: positive-positive; light purple line: $\pi$-alkyl) with the amino acid residues on the active site of the PBP2a receptor. 
Table 4. Data of interactions resulting from the molecular docking of compounds 8, 9, 10, and CHX into PBP2a.

\begin{tabular}{|c|c|c|c|c|c|c|c|}
\hline \multicolumn{4}{|c|}{ Compound 9} & \multicolumn{4}{|c|}{ CHX } \\
\hline $\begin{array}{l}\text { Amino Acid } \\
\text { Residue }\end{array}$ & Interactions & With & $\begin{array}{c}\text { Bonding } \\
\text { Distance (Å) }\end{array}$ & $\begin{array}{l}\text { Amino Acid } \\
\text { Residue }\end{array}$ & Interactions & With & $\begin{array}{c}\text { Bonding } \\
\text { Distance (Å) }\end{array}$ \\
\hline Ser403 & H-Bond & $\mathrm{NH}$ & 2.21 & Lys430 & $\begin{array}{c}\text { Unfavorable } \\
\text { positive-positive }\end{array}$ & $\mathrm{NH}$ & 5.26 \\
\hline \multirow{2}{*}{ Asn 464} & H-Bond & $\mathrm{NH}$ & 2.74 & \multirow{2}{*}{ Asn 464} & H-Bond & $\mathrm{NH}$ & 3.05 \\
\hline & H-Bond & $\mathrm{C}=\mathrm{O}$ & 2.40 & & H-Bond & $\mathrm{NH}$ & 2.85 \\
\hline Tyr519 & $\mathrm{C}-\mathrm{H}$ bond & Pyrrole & 3.71 & Tyr519 & H-Bond & $\mathrm{NH}$ & 2.88 \\
\hline His583 & $\begin{array}{l}\text { Unfavorable } \\
\text { Donor-donor }\end{array}$ & $\mathrm{OH}$ & 1.23 & His583 & $\pi$-alkyl & $\mathrm{Cl}$ & 4.35 \\
\hline Met641 & $\pi$-sulphur & Benzene & 4.91 & Lys406 & $\begin{array}{c}\text { Unfavorable } \\
\text { positive-positive }\end{array}$ & $\mathrm{NH}$ & 3.87 \\
\hline Tyr446 & $\pi-\pi$ stacked & Benzene & 4.55 & Ser462 & H-Bond & $\mathrm{NH}$ & 2.89 \\
\hline \multicolumn{4}{|c|}{ Compound 8} & \multicolumn{4}{|c|}{ Compound 10} \\
\hline Ala642 & $\pi$-alkyl & Benzene & 4.84 & Tyr446 & $\begin{array}{l}\pi-\pi \text { T-shaped } \pi-\pi \\
\text { stacked }\end{array}$ & Benzene & 3.98 \\
\hline Tyr446 & $\pi-\pi$ T-shaped & Benzene & 5.09 & Met641 & $\pi$-sulphur & Benzene & 5.11 \\
\hline Met641 & $\pi$-alkyl & Benzene & 5.20 & Asn 464 & H-Bond & $\mathrm{NH}$ & 2.80 \\
\hline \multirow{3}{*}{ Asn464 } & H-Bond & $\mathrm{NH}$ & 2.82 & & H-Bond & $\mathrm{C}=\mathrm{O}$ & 2.22 \\
\hline & H-Bond & $\mathrm{C}=\mathrm{O}$ & 2.32 & \multirow[b]{2}{*}{ Tyr519 } & C-H Bond & Pyrrole & 5.69 \\
\hline & $\pi$-donor H-Bond & Pyrrole & 2.79 & & $\begin{array}{c}\pi-\pi \text { T-shaped } \pi-\pi \\
\text { stacked }\end{array}$ & Pyrrole & 3.72 \\
\hline Tyr519 & $\pi-\pi$ T-shaped & Pyrrole & 5.77 & & & & \\
\hline
\end{tabular}

Meanwhile, slightly lower binding affinities were observed in compounds $8(-6.9 \mathrm{kcal} / \mathrm{mol})$ and $10(-6.7 \mathrm{kcal} / \mathrm{mol})$ compared to compound 9. Similarly, both compounds formed strong hydrogen bonds with Asn464 in the PBP2a binding site through the -NH of pyrrole and carbonyl moieties of the respective analogues $\mathbf{8}$ and $\mathbf{1 0}$ (Figure 3). However, it is presumed that a lack of an essential interaction with His583, together with the multiple hydrophobic interactions with the amino acid residues of PBP2a leads to the reduction in the binding affinity, thus lowering their anti-MRSA potential.

Hence, the morphological changes of the MRSA-bacterial cells when treated with this promising antimicrobial agent, analogue 9 was further investigated using the scanning electron microscopy (SEM) analysis.

\subsection{Scanning Electron Microscope (SEM) Analysis}

The cell structures of the untreated standard and clinical 172918 S. aureus strains are shown in Figures 4A and 5A. These untreated cells served as a control and occurred as compact evenly shaped grape-like cluster cells with a round to oval cocci that have a smooth surface. Meanwhile, Figures 4B and 5B illustrate the morphology of both standard and clinical 172918 S. aureus cells after a two-hour exposure to compound $\mathbf{9}$. The bacterial cells were observed to be larger, irregular in shape, and partially disintegrated. Based on the results, it was determined that the bacterial morphology was altered from its smooth cell surface to shrunken and distorted after the treatment, suggesting the bactericidal property of compound 9 . 

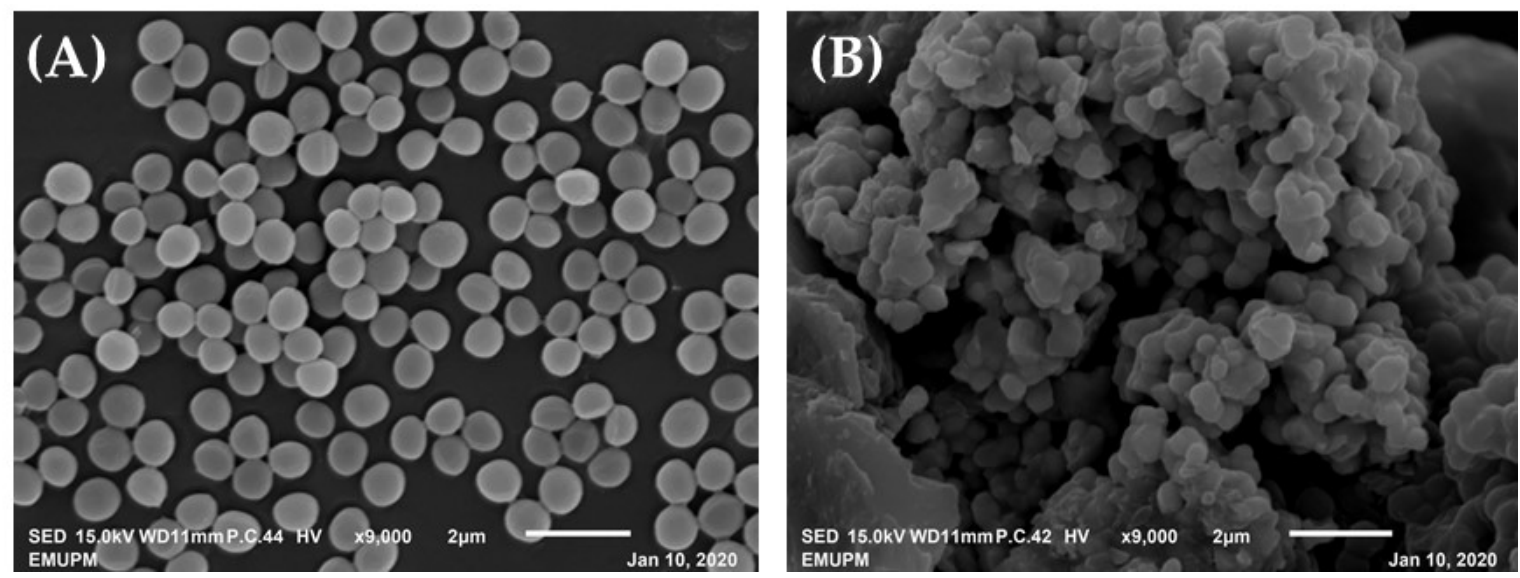

Figure 4. Scanning electron micrograph of (A) untreated and (B) treated with $1 \%$ of compound 9 on the standard MRSA ATCC 700699 cells for two hours.
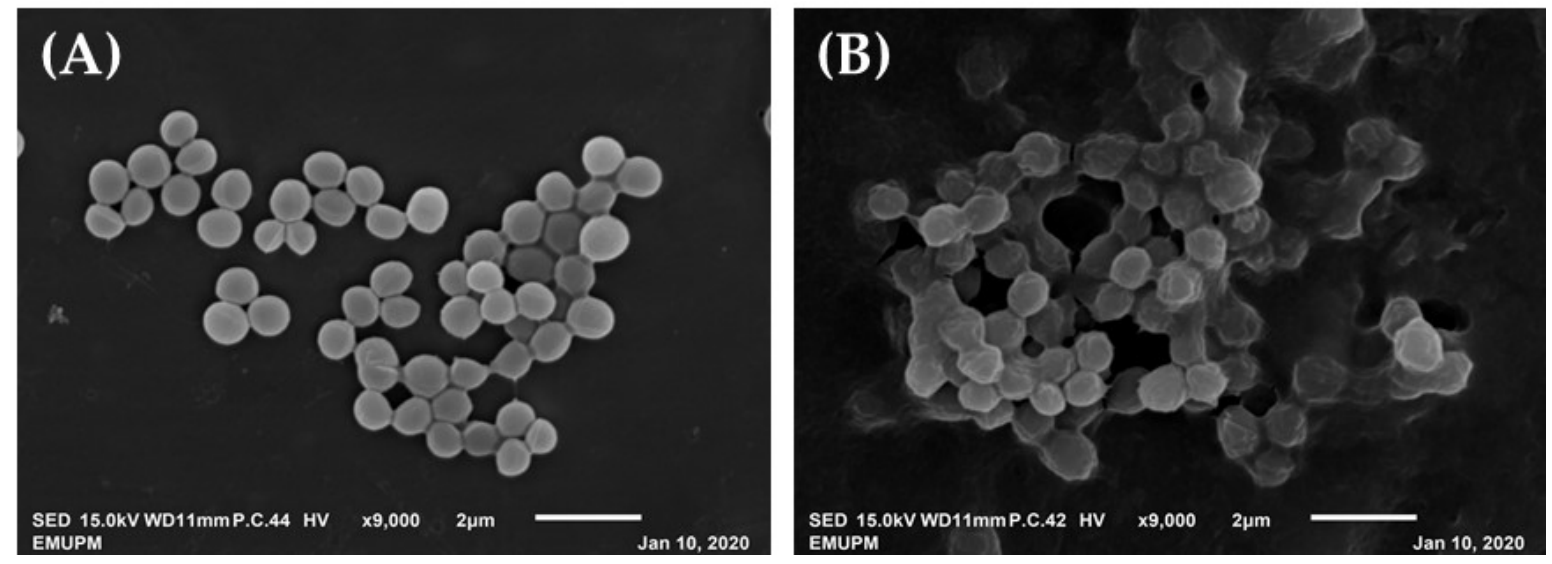

Figure 5. Scanning electron micrograph of (A) untreated and (B) treated with $1 \%$ of compound 9 on the clinical MRSA 172918 cells for two hours.

\subsection{In Vivo Toxicity Profile in Zebrafish Model}

We then employ an animal-based testing approach to preliminary evaluate the toxicologic profile of the most bioactive chemical in the series. Zebrafish (Danio rerio) have been extensively used as a toxicological model for drug screening purposes to treat various human diseases [28]. Based on the phylogenetic analyses of fish and human genomes, humans and zebrafishes share approximately $70 \%$ similar morphology and physiology in the nervous, cardiovascular, and digestive systems [29]. Additionally, the zebrafish genome is completely sequenced, and $84 \%$ of its genes were homologous to disease-related genes found in the human genome [30]. Furthermore, zebrafish can also provide valuable data for other vertebrate animals, allowing researchers to link biochemical, genetic, and cellular hypotheses to high-performance observations at structural, functional, and behavioural levels [31]. In the last two decades, the zebrafish embryotoxicity test or fish embryotoxicity test, has been gaining interest as it provides a total and well-defined developmental period for a vertebrate embryo, enabling the study of its early life stages [32]. Although both adults and embryos are proven useful for toxicology studies, embryos are more ideal and significant for toxicity profiling due to the transparency of the egg, which allows for easy detection and evaluation of the respective developmental phases and endpoints during the toxicity test [33,34]. The zebrafish model has technological and economic advantages over mammal models, particularly rodents $[31,35]$ in reducing the number of substances and expenses required when using animals in drug tests and production [36]. 
To describe the toxic effects of analogue 9 , we first treated the zebrafish embryos with various dosages of the tested compound $(10,20,40,75,150,300,600$, and $1200 \mu \mathrm{M})$ starting from $6 \mathrm{hpf}$ via the bath immersion technique. At 30 and $54 \mathrm{hpf}$, morphological comparisons were made between the exposed and control embryos to observe any morphological abnormalities.

Based on Figure 6C, the results revealed that the 9-treated embryos were alive at $30 \mathrm{hpf}$ with no significant morphological defects detected up to $40 \mu \mathrm{M}$ in a 24-h treatment. We then further investigated the toxicity of compound 9 via a transgenic line of zebrafish that particularly expresses green fluorescent protein (GFP) in their vascular endothelial cells, $T g(k d r l: e g f p)$ to gain significant insight into the pathological blood vessel formation of the embryos. No adverse effects were observed towards the normal development of the vasculature up to $40 \mu \mathrm{M}$ on the 9-exposed late gastrula $10 \mathrm{hpf} T g(k d r l: e g f p)$ embryos, as illustrated in Figure 6D. However, the assayed embryos show some developmental delays when treated with high concentrations; $\geq 300 \mu \mathrm{M}$ in a 24 -h treatment (Figure $6 \mathrm{~A}$ ) and $\geq 75 \mu \mathrm{M}$ in a 48 -h treatment of compound 9 (Figure $6 \mathrm{~B}$ ), respectively.

(A)

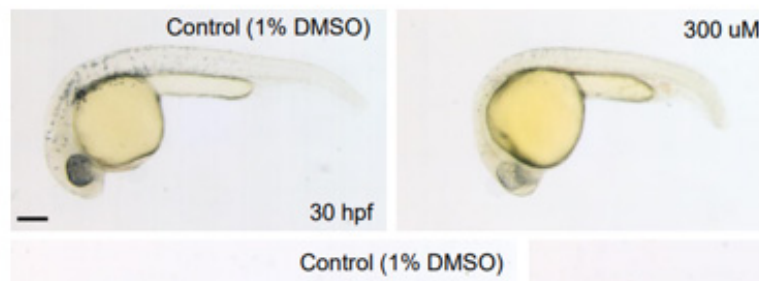

(B)

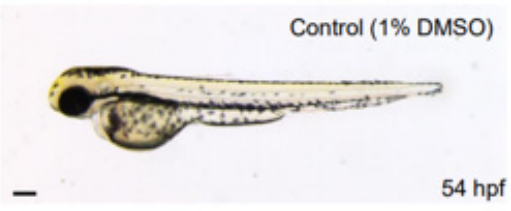

(C)

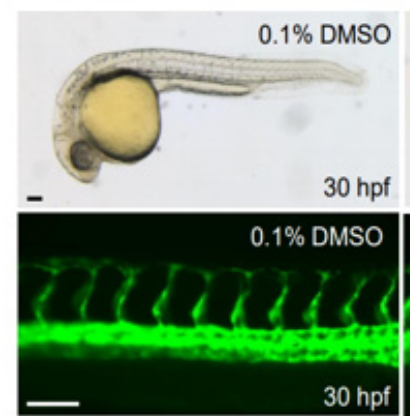

$54 \mathrm{hpf}$
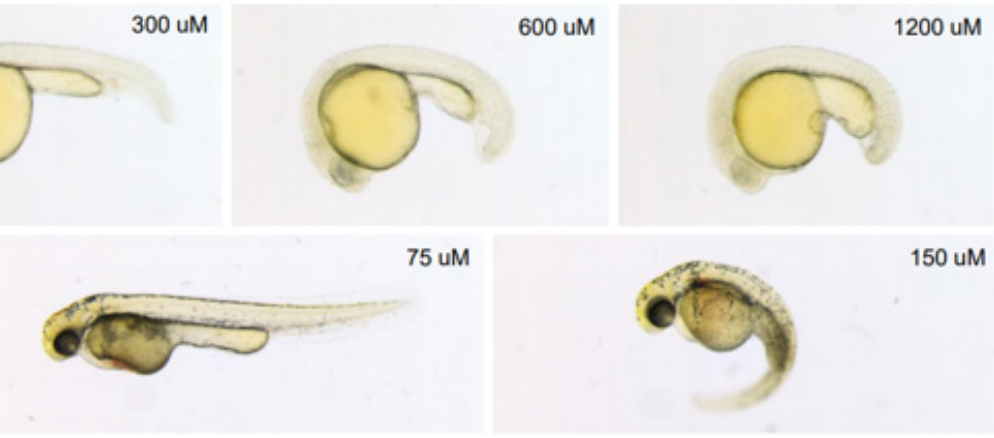

$00 \mathrm{uM}$
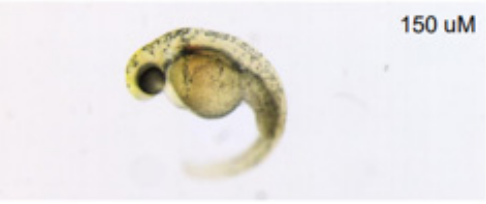

Scale bar: 200 um

(D)
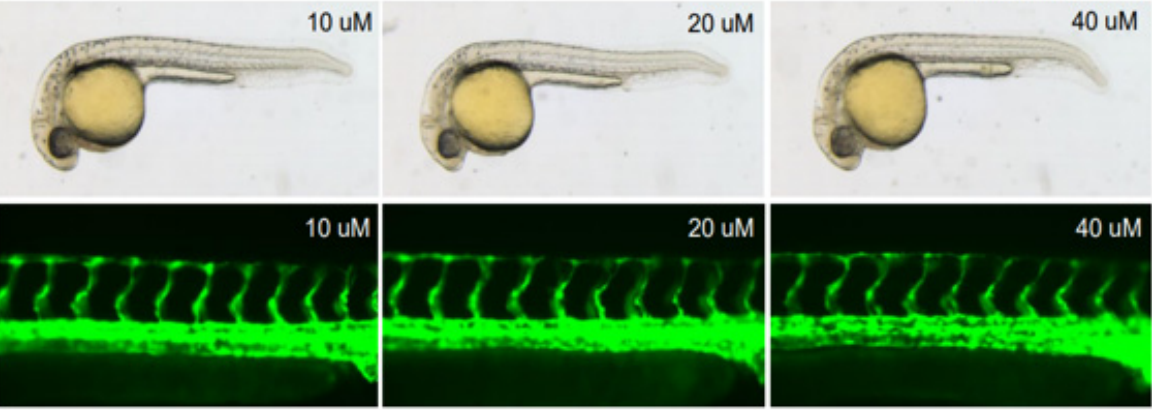

scale bar: 100 um

Figure 6. Morphological features of zebrafish embryos at different developmental stages. (A) At 30 hpf after a 24-h exposure to analogue 9 at concentrations of 300,600, and $1200 \mu \mathrm{M},(\mathbf{B})$ at $54 \mathrm{hpf}$ after a 48-h exposure to analogue 9 at concentrations of 75 and $150 \mu \mathrm{M}$, as well as (C) at $30 \mathrm{hpf}$ after a 24-h exposure to analogue 9 at concentrations of 10, 20, and $40 \mu \mathrm{M}$. (D) Effects of analogue 9 at concentrations 10, 20, and $40 \mu \mathrm{M}$ on blood vessel development in transgenic zebrafish, $\mathrm{Tg}(\mathrm{kdrl} / \mathrm{eg} f \mathrm{p})$ at $30 \mathrm{hpf}$, same embryos as in (C). Vasculogenesis and angiogenesis in the trunk region were normal in both the control and analogue 9 -treated zebrafish.

To further assess the apoptotic properties of $\mathbf{9}$, the treated embryos were assayed at 10 , 20 , and $40 \mu \mathrm{M}$ concentrations in a 24-h treatment via a fluorescent vital dye, acridine orange (AO) to mark dead and/or apoptotic cells at $96 \mathrm{hpf}$. Apoptosis is an essential component in a normal developmental process of various tissues and organ systems and is often characterized by a specific cellular shrinkage, membrane blebbing, nuclear condensation, and nuclear fragmentation, all of which are well-known hallmarks of this type of cell death [37]. Based on Figure 7, the AO-positive cells were sparsely detected in the bodies of the control and 9-treated transgenic zebrafish at all tested concentrations in a similar pattern. The results signify that compound 9 has no negative interventions on the normal development of zebrafish embryos compared to the DMSO-vehicle control larvae. 
(A)

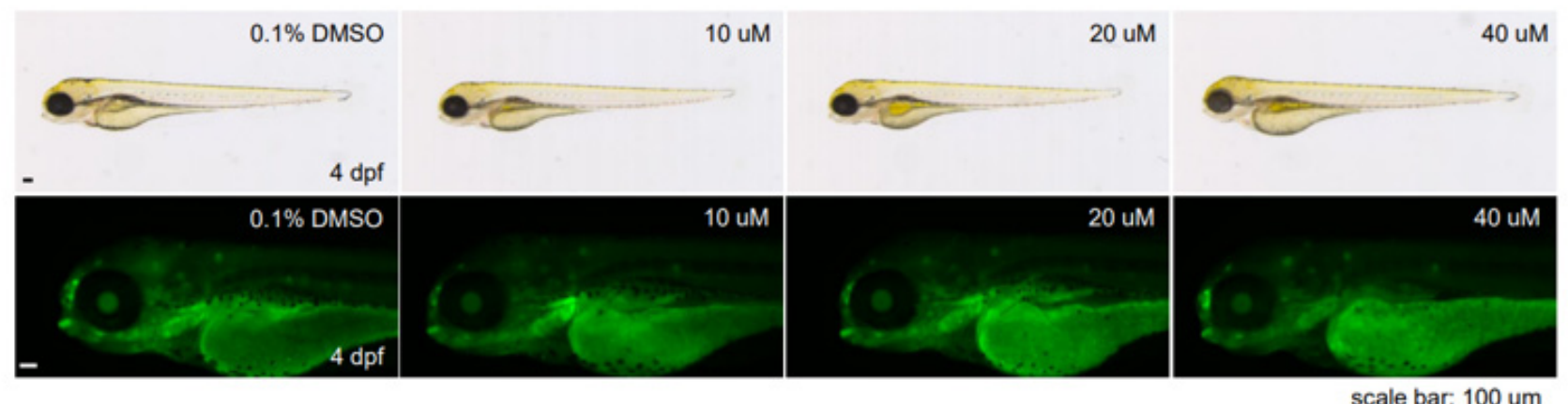

Figure 7. (A) Effects of compound 9 on later stage zebrafish larvae (4 dpf) at their respective concentrations of 10, 20, and $40 \mu \mathrm{M}$. (B) Detection of apoptosis or cell death via acridine orange, fluorescent vital dye staining. Non-specific signals in yolk and eye lens are autofluorescence shown in both the control and compound 9-treated animals.

\section{Materials and Methods}

\subsection{In Silico Pan-Assay Interference Compounds (PAINS) Identification}

All pyrrolylated-chalcone chemical structures were drawn using ChemDraw Ultra 12.0 and subsequently converted to SMILES (Simplified Molecular Input Line Entry System) format. The SMILES formulas were then converted into Symyx SDF (Spatial Data File) file format as recommended by the FAF-Drugs4 Bank Formatter (http: //mobyle.rpbs.univ-paris-diderot.fr/cgi-bin/portal.py\#forms::Bank-Formatter, accessed on 30 September 2020), and subsequently submitted into the FAF-Drugs4 server (http: // mobyle.rpbs.univ-paris-diderot.fr/cgi-bin/portal.py\#forms::FAF-Drugs4, accessed on 30 September 2020) for the filtration of PAINS using the PAINS filters A, B, and C [38]. The generated results are available at the following address (https: / / mobyle.rpbs.univparis-diderot.fr / cgi-bin/portal.py?form=admetox\#jobs::FAF-Drugs4.U06888724708080, accessed on 30 September 2020).

\subsection{General}

All the chemicals and reagents used in the synthesis and biological evaluation experiments were purchased from Merck (Kenilworth, NJ, USA), Alfa Aesar (Haverhill, MA, USA), Sigma Aldrich (St. Louis, MO, USA), Acros Organics (Carlsbad, CA, USA), and Systerm (Shah Alam, Malaysia). The melting points of the synthesized compounds were determined using XSP-12 model $500 \times$ Fisher-Johns aluminium heating stage melting point apparatus equipped with an adjustable magnifier Model 12-144 (American Laboratory Trading, Cambridge, MA, USA). 1D ( ${ }^{1} \mathrm{H}-\mathrm{NMR},{ }^{13} \mathrm{C}-\mathrm{NMR}$, and $\left.{ }^{19} \mathrm{~F}-\mathrm{NMR}\right)$ and 2D (COSY, HSQC, and HMBC) NMR spectra were recorded using Bruker AV $500 \mathrm{MHz}$ and Bruker's $700 \mathrm{MHz}$ ASCEND ${ }^{\mathrm{TM}}$ NMR spectrometer (Bruker, Karlsruhe, Germany). The mass spectra for known compounds (including the new analogue 5 , due to the sample unavailability for UHPLC-ESI-HRMS) were determined using a Shimadzu GCMS-QP2010 Plus (Shimadzu, Kyoto, Japan), whilst the UHPLC-ESI-HRMS spectra of the new analogues 11-15 was measured with a Thermo Fisher Scientific ${ }^{\mathrm{TM}}$ Model Q Exactive ${ }^{\mathrm{TM}}$ Hybrid QuadrupoleOrbitrap mass spectrometer (Thermo Fisher Scientific, Waltham, MA, USA), in which both analyses were performed via direct injection. The FT-IR spectrum was recorded on a Perkin Elmer RX1 FT-IR spectrometer (Perkin Elmer, Waltham, MA, USA) in the mid-IR region (400-4000 $\mathrm{cm}^{-1}$ ). The methicillin-resistant S. aureus (MRSA) ATCC 700699 was purchased from American Type Culture Collection (ATCC) (ATCC, Manassas, VA, USA), while the three clinical MRSA strains $(172918,180620$, and 180865) were obtained from the Microbial Collection of the Natural Medicines and Product Research Laboratory, Institute of Bioscience, UPM. 


\subsection{Synthesis}

The known pyrrolylated-chalcones (1-4 and 6-10) were synthesized following the method as described by Mohd Faudzi et al. (2020) [9]. The general and spectrometry data, including the percentage yield and melting point, of the synthesized molecules 1-15 was tabulated in Table S1 of Supplementary Materials.

3.3.1. General Procedure for the Synthesis of New 3-(2-Nitrophenyl)-1-(1H-pyrrol-2-yl) Prop-2-en-1-one (5)

Firstly, $10 \mathrm{~mL}$ of $\mathrm{NaOH}(6 \mathrm{M})$ was dissolved in $6 \mathrm{~mL}$ of water and cooled at $0{ }^{\circ} \mathrm{C}$ in an ice bath, followed by the addition of $10 \mathrm{~mL}$ of $95 \%$ ethanol into the diluted $\mathrm{NaOH}$ solution, of which was carried out slowly. The reaction flask was then removed from the ice bath and was left at room temperature. Following that, an equimolar quantity of 2-acetylpyrrole $(1.091 \mathrm{~g} / 1.00 \mathrm{mmol})$ and 2-nitrobenzaldehyde $(0.1511 \mathrm{~g} / 1.00 \mathrm{mmol})$ was slowly added to the mixture. The reaction mixture was stirred for $2 \mathrm{~h}$ at room temperature and cooled at $0{ }^{\circ} \mathrm{C}$ for $24 \mathrm{~h}$. The precipitates formed were filtered, washed with cold water, and recrystallized with ethanol. The resulting product was a grey cotton $(2.90 \%) ; \mathrm{mp}$ 193-194 ${ }^{\circ} \mathrm{C}$; IR (UATR) $3240(\mathrm{NH}), 1643(\mathrm{C}=\mathrm{O}), 1581(\mathrm{C}=\mathrm{C}), 1508$ and $1404\left(\mathrm{NO}_{2}\right) \mathrm{cm}^{-1}$; ${ }^{1} \mathrm{H}$ NMR $\left(700 \mathrm{MHz}\right.$, DMSO- $\left.d_{6}\right) \delta: 6.37(m, 1 \mathrm{H}, \mathrm{Py}-\mathrm{H}), 7.37(t, J=3.1 \mathrm{~Hz}, 1 \mathrm{H}, \mathrm{Py}-\mathrm{H}), 7.42(t d$, $J=1.1$ and $7.4 \mathrm{~Hz}, 1 \mathrm{H}, \mathrm{Ar}-\mathrm{H}), 7.64(\mathrm{~s}, 1 \mathrm{H}, \mathrm{Py}-\mathrm{H}), 7.77(t d, J=1.2$ and $7.6 \mathrm{~Hz}, 1 \mathrm{H}, \mathrm{Ar}-\mathrm{H}), 8.00$ $(d d, J=1.6$ and $7.6 \mathrm{~Hz}, 1 \mathrm{H}, \mathrm{Ar}-\mathrm{H}), 8.63(d, J=8.3 \mathrm{~Hz}, 1 \mathrm{H}, \mathrm{Ar}-\mathrm{H}), 10.0(s, 1 \mathrm{H}, \mathrm{NH}), 12.30(b r$. $s, 2 \mathrm{H}, \mathrm{CH}=\mathrm{CH}) ;{ }^{13} \mathrm{C}$ NMR $\left(175 \mathrm{MHz}\right.$, DMSO- $\left.d_{6}\right) \delta: 112.2,120.0,123.7,124.9,128.6,130.2$, 136.2, 136.6, 138.6, 161.2, 173.5, 196.5; $m / z$ (DI-MS) $242\left(\mathrm{M}^{+}, \mathrm{C}_{13} \mathrm{H}_{10} \mathrm{~N}_{2} \mathrm{O}_{3}\right.$ requires 242).

\subsubsection{General Procedure for the Synthesis of New Difluorinated Compounds (11-15)}

Two mmol of 2-acetylpyrrole and substituted benzaldehyde were dissolved in $5 \mathrm{~mL}$ of $95 \%$ ethanol and the mixture was stirred for $5 \mathrm{~min}$, followed by a dropwise addition of $1 \mathrm{~mL}$ of $\mathrm{NaOH}(6 \mathrm{M})$. The reaction mixture was then left to stir overnight at room temperature. Once the reaction was completed, crushed ice was added to quench the reaction. Following that, diluted $\mathrm{HCl}$ was added to neutralize the reaction mixture before being further extracted with ethyl acetate $(3 \times 10 \mathrm{~mL})$. The organic layer was collected, dried with anhydrous $\mathrm{MgSO}_{4}$, and evaporated under reduced pressure. The crude products were purified by column chromatography and/or recrystallization techniques to yield pure compounds [9]. The chemical characterization was only discussed for the newly synthesized molecules.

\section{3-(2,3-Difluorophenyl)-1-(1H-pyrrol-2-yl) Prop-2-en-1-one (11)}

Following the general procedure stated in Section 3.3.2, 2-acetylpyrrole $(0.2183 \mathrm{~g} / 2.00 \mathrm{mmol})$ reacted with 2,3-difluorobenzaldehyde $(218 \mu \mathrm{L} / 2.00 \mathrm{mmol})$ and was recrystallized with ethanol. The resulting product was yellow in colour (65.37\%); mp $142-143{ }^{\circ} \mathrm{C}$; IR (UATR) $3230(\mathrm{NH}), 1643(\mathrm{C}=\mathrm{O}), 1579(\mathrm{C}=\mathrm{C}), 1280(\mathrm{C}-\mathrm{F}) \mathrm{cm}^{-1} ;{ }^{1} \mathrm{H}$ NMR $\left(500 \mathrm{MHz}\right.$, acetone- $\left.d_{6}\right) \delta$ : $6.34(m, 1 \mathrm{H}, \mathrm{Py}-\mathrm{H}), 7.27$ (m, 1H, Py-H), $7.30(m, 1 \mathrm{H}, \mathrm{Ar}-\mathrm{H}), 7.32(m, 1 \mathrm{H}, \mathrm{Py}-\mathrm{H}), 7.40(m$, $1 \mathrm{H}, \mathrm{Ar}-\mathrm{H}), 7.75(d, J=15.9 \mathrm{~Hz}, 1 \mathrm{H}, \mathrm{CH}=\mathrm{CH}), 7.78(d d, J=1.5$ and $6.5 \mathrm{~Hz}, 1 \mathrm{H}, \mathrm{Ar}-\mathrm{H}), 7.85$ $(d, J=15.8,1 \mathrm{H}, \mathrm{CH}=\mathrm{CH}), 11.15$ (br. s, $1 \mathrm{H}, \mathrm{NH}) ;{ }^{13} \mathrm{C}$ NMR $\left(125 \mathrm{MHz}\right.$, acetone- $\left.d_{6}\right) \delta: 110.3$, $116.9,118.2,123.8,124.8,125.4,126.2,131.2,133.2,148.9,150.7,177.2 ;{ }^{19}$ F NMR $(470 \mathrm{MHz}$, acetone- $d_{6}$ ) $\delta:-140.2$ and -143.6 ; HRMS (ESI): $m / z$ calcd for $\mathrm{C}_{13} \mathrm{H}_{9} \mathrm{~F}_{2} \mathrm{NO}-\mathrm{H}^{-}: 232.0580$ $[\mathrm{M}-\mathrm{H}]^{-}$; found: 232.0577 .

\section{3-(2,4-Difluorophenyl)-1-(1H-pyrrol-2-yl) Prop-2-en-1-one (12)}

Following the general procedure stated in Section 3.3.2, 2-acetylpyrrole $(0.2183 \mathrm{~g} / 2.00 \mathrm{mmol})$ reacted with 2,4-difluorobenzaldehyde $(218 \mu \mathrm{L} / 1.99 \mathrm{mmol})$ and was purified with column chromatography, Hexane: EtOAc (7:3) and recrystallized with acetone. The resulting product was a pale white solid (90.23\%); mp 118-119 ${ }^{\circ} \mathrm{C}$; IR (UATR) $3251(\mathrm{NH}), 1643(\mathrm{C}=\mathrm{O})$, $1571(\mathrm{C}=\mathrm{C}), 1273(\mathrm{C}-\mathrm{F}) \mathrm{cm}^{-1} ;{ }^{1} \mathrm{H}$ NMR (500 MHz, acetone- $\left.d_{6}\right) \delta: 6.33$ (br. s, 1H, Py-H), 7.15 (m, 2H, Ar-H), 7.26 (br. s, 1H, Py-H), 7.29 (br. s, 1H, Py-H), $7.70(d, J=15.8,1 \mathrm{H}, \mathrm{CH}=\mathrm{CH})$, 
$7.83(d, J=15.8,1 \mathrm{H}, \mathrm{CH}=\mathrm{CH}), 8.06(d d, J=7.1$ and $8.3 \mathrm{~Hz} 1 \mathrm{H}, \mathrm{Ar}-\mathrm{H}), 11.13$ (br. $s, 1 \mathrm{H}, \mathrm{NH})$; ${ }^{13} \mathrm{C}$ NMR $\left(125 \mathrm{MHz}\right.$, acetone- $\left.d_{6}\right) \delta: 104.2,110.2,112.1,116.7,119.8,124.6,125.9,130.3,131.5$, 133.2, 161.6, 163.8, 177.4; ${ }^{19} \mathrm{~F}$ NMR (470 MHz, acetone- $\left.d_{6}\right) \delta:-108.3$ and -112.9 ; HRMS (ESI): $m / z$ calcd for $\mathrm{C}_{13} \mathrm{H}_{9} \mathrm{~F}_{2} \mathrm{NO}-\mathrm{H}^{-}: 232.0580[\mathrm{M}-\mathrm{H}]^{-}$; found: 232.0579 .

3-(2,5-Difluorophenyl)-1-(1H-pyrrol-2-yl) Prop-2-en-1-one (13)

Following the general procedure stated in Section 3.3.2, 2-acetylpyrrole $(0.2183 \mathrm{~g} / 2.00 \mathrm{mmol})$ reacted with 2,5-difluorobenzaldehyde $(218 \mu \mathrm{L} / 2.00 \mathrm{mmol})$ and was recrystallized with methanol. The resulting product was a pale white solid $(85.28 \%)$; mp $124-125^{\circ} \mathrm{C}$; IR (UATR) $3228(\mathrm{NH}), 1651(\mathrm{C}=\mathrm{O}), 1487(\mathrm{C}=\mathrm{C}), 1271(\mathrm{C}-\mathrm{F}) \mathrm{cm}^{-1} ;{ }^{1} \mathrm{H}$ NMR (500 MHz, acetone- $\left.d_{6}\right) \delta$ : $6.34(m, 1 \mathrm{H}, \mathrm{Py}-\mathrm{H}), 7.28(m, 1 \mathrm{H}, \mathrm{Py}-\mathrm{H}), 7.31(d d, J=4.7$ and $9.2 \mathrm{~Hz}, 2 \mathrm{H}, \mathrm{Ar}-\mathrm{H}), 7.36(m, 1 \mathrm{H}$, Py-H), $7.78(d, J=15.8,1 \mathrm{H}, \mathrm{CH}=\mathrm{CH}), 7.81(m, 1 \mathrm{H}, \mathrm{Py}-\mathrm{H}), 7.84(d, J=16.1,1 \mathrm{H}, \mathrm{CH}=\mathrm{CH}), 11.14$ (br. s, 1H, NH); ${ }^{13} \mathrm{C}$ NMR (125 MHz, acetone- $\left.d_{6}\right) \delta: 110.3,114.2,117.0,117.5,118.1,124.6$, $126.1,126.2,131.1,133.2,157.2,159.2,177.2 ;{ }^{19} \mathrm{~F} \mathrm{NMR}\left(470 \mathrm{MHz}\right.$, acetone- $\left.d_{6}\right) \delta:-119.8$ and -123.4; HRMS (ESI): $m / z$ calcd for $\mathrm{C}_{13} \mathrm{H}_{9} \mathrm{~F}_{2} \mathrm{NO}_{-} \mathrm{H}^{-}: 232.0580[\mathrm{M}-\mathrm{H}]^{-}$; found: 232.0570 .

\section{3-(3,4-Difluorophenyl)-1-(1H-pyrrol-2-yl) Prop-2-en-1-one (14)}

Following the general procedure stated in Section 3.3.2, 2-acetylpyrrole $(0.2183 \mathrm{~g} / 2.00 \mathrm{mmol})$ reacted with 3,4-difluorobenzaldehyde $(218 \mu \mathrm{L} / 1.98 \mathrm{mmol})$ and was recrystallized with EtOH: Acetone (5:5). The resulting product was a yellow solid (47.51\%); mp $152-153{ }^{\circ} \mathrm{C}$; IR (UATR) 3253 (NH), 1645 (C=O), 1570 (C=C), 1269 (C-F) cm ${ }^{-1}$; ${ }^{1} \mathrm{H}$ NMR (500 MHz, acetone- $\left.d_{6}\right) \delta: 6.33(\mathrm{~m}, 1 \mathrm{H}, \mathrm{Py}-\mathrm{H}), 7.24(\mathrm{~m}, 1 \mathrm{H}, \mathrm{Py}-\mathrm{H}), 7.34(\mathrm{~m}, 1 \mathrm{H}, \mathrm{Py}-\mathrm{H}), 7.42(\mathrm{~m}, 1 \mathrm{H}$, Ar-H), $7.64(\mathrm{~m}, 1 \mathrm{H}, \mathrm{Ar}-\mathrm{H}), 7.66(\mathrm{~d}, J=16.1,1 \mathrm{H}, \mathrm{CH}=\mathrm{CH}), 7.70(\mathrm{~d}, J=15.7,1 \mathrm{H}, \mathrm{CH}=\mathrm{CH})$, 7.88 (m, 1H, Ar-H), 11.08 (br. s, $1 \mathrm{H}, \mathrm{NH}) ;{ }^{13} \mathrm{C}$ NMR $\left(125 \mathrm{MHz}\right.$, acetone- $\left.d_{6}\right) \delta: 110.2,116.3$, $116.8,117.7,124.0,125.7,125.8,133.2,133.3,138.4,149.7,151.7,177.4 ;{ }^{19} \mathrm{~F}$ NMR $(470 \mathrm{MHz}$, acetone- $d_{6}$ ) $\delta:-137.6$ and -139.5 ; HRMS (ESI): $m / z$ calcd for $\mathrm{C}_{13} \mathrm{H}_{9} \mathrm{~F}_{2} \mathrm{NO}^{-\mathrm{H}^{-}}: 232.0580$ $[\mathrm{M}-\mathrm{H}]^{-}$; found: 232.0569 .

\section{3-(3,5-Difluorophenyl)-1-(1H-pyrrol-2-yl) Prop-2-en-1-one (15)}

Following the general procedure stated in Section 3.3.2, 2-acetylpyrrole $(0.2183 \mathrm{~g} / 2.00 \mathrm{mmol})$ reacted with 3,5-difluorobenzaldehyde $(218 \mu \mathrm{L} / 1.99 \mathrm{mmol})$ and was recrystallized with methanol. The resulting product was a yellow solid (69.72\%); mp 151-152 ${ }^{\circ} \mathrm{C}$; IR (UATR) $3243(\mathrm{NH}), 1649(\mathrm{C}=\mathrm{O}), 1581(\mathrm{C}=\mathrm{C}), 1301(\mathrm{C}-\mathrm{F}) \mathrm{cm}^{-1},{ }^{1} \mathrm{H}$ NMR (500 MHz, acetone- $\left.d_{6}\right) \delta$ : $6.34(m, 1 \mathrm{H}, \mathrm{Py}-\mathrm{H}), 7.09(t t, \mathrm{~J}=2.3$ and $9.1 \mathrm{~Hz} 1 \mathrm{H}, \mathrm{Ar}-\mathrm{H}), 7.26(m, 1 \mathrm{H}, \mathrm{Py}-\mathrm{H}), 7.39(m, 1 \mathrm{H}$, Py-H), 7.50 (br. $d, J=2.1,1 \mathrm{H}, \mathrm{Ar}-\mathrm{H}), 7.52$ (br d, $J=2.1,1 \mathrm{H}, \mathrm{Ar}-\mathrm{H}), 7.67$ (d, J= 15.7, 1H, $\mathrm{CH}=\mathrm{CH}), 7.79(d, J=15.7,1 \mathrm{H}, \mathrm{CH}=\mathrm{CH}), 11.10($ br. $s, 1 \mathrm{H}, \mathrm{NH}) ;{ }^{13} \mathrm{C}$ NMR $(125 \mathrm{MHz}$, acetone$\left.d_{6}\right) \delta: 104.5,110.3,110.9,111.1,117.0,125.5,126.1,133.3,138.1,139.3,162.3,164.3,177.3$; ${ }^{19} \mathrm{~F}$ NMR (470 MHz, acetone- $\left.d_{6}\right) \delta:-111.1$; HRMS (ESI): $m / z$ calcd for $\mathrm{C}_{13} \mathrm{H}_{9} \mathrm{~F}_{2} \mathrm{NO}_{-} \mathrm{H}^{-}$: 232.0580 [M - H] $]^{-}$; found: 232.0569.

\subsection{In Vitro Evaluation of the Anti-MRSA Activity \\ 3.4.1. Disc Diffusion Assay}

The synthesized compounds were screened for their anti-MRSA potential against the standard ATCC and three clinical MRSA bacterial strains via a disc diffusion assay (DDA). The DDA was conducted following the method suggested by the Clinical and Laboratory Standard Institute (CLSI) 2012 [39]. A single uniform colony of inoculum was prepared and immediately spread on an MHA plate with a sterile cotton swab. Sterile filter paper discs with a diameter of $6 \mathrm{~mm}$ were placed on top of the culture, each paper discs were permeated with $10 \mu \mathrm{L}$ of the respective test compounds $(1 \mathrm{mg} / 100 \mu \mathrm{L})$ at a $1 \%$ concentration. For activity comparisons, $0.1 \% \mathrm{CHX}$ and $10 \%$ DMSO were used as positive and negative controls. After a $24-\mathrm{h}$ incubation time at $37^{\circ} \mathrm{C}$, the inhibition zones were measured and recorded in millimetres. The assay was carried out once in duplicates $(n=1 \times 2)$. 


\subsubsection{Determination of Minimum Inhibitory Concentration and Minimum Bactericidal Concentration}

The minimum inhibitory concentration (MIC) was determined by a two-fold broth microdilution method using a 96-well round-bottom microtiter plate (Greiner Bio-One, Frickenhausen, Germany) with an inoculum suspension of all the bacteria strains at approximately $10^{6}$ to $10^{8} \mathrm{CFU} / \mathrm{mL}$ [21]. Each well on the first column was filled with $100 \mu \mathrm{L}$ of $\mathrm{MHB}$, which serves as the negative growth control, while each well on the second column was filled with $100 \mu \mathrm{L}$ of the bacterial suspension as a positive control for cell growth. The microdilution was performed at varying concentrations of the test samples, ranging from $5 \mathrm{mg} / \mathrm{mL}$ (in column 12) to $0.01 \mathrm{mg} / \mathrm{mL}$ (in column 3). The concentrations of the positive control, CHX ranged from $500 \mu \mathrm{g} / \mathrm{mL}$ (in column 12) to $0.97 \mu \mathrm{g} / \mathrm{mL}$ (in column 3). Subsequently, the plates were incubated for $24 \mathrm{~h}$ at $37^{\circ} \mathrm{C}$. The MIC value was determined by the lowest compound concentration that produces no visible growth in the wells [40].

Following that, the minimum bactericidal concentration (MBC) was determined by sub-culturing the $10 \mu \mathrm{L}$ suspension from each MIC well (columns 1-12) onto an MHA plate. The plates were then incubated at $37^{\circ} \mathrm{C}$ for $24 \mathrm{~h}$ or until bacteria growth was observed at the growth control plates. MBC was defined as the minimum concentration of tested samples that is needed to kill bacteria on the MHA plates. The MIC and MBC values were expressed as the means \pm standard deviation (SD); $n=2 \times 3$.

\subsubsection{Determination of Time-Kill Curve}

The time-kill assay for compounds 8, 9, and $\mathbf{1 0}$ was carried out against the ATCC and clinical MRSA strains according to the method described by the CLSI (2012) [39], with a few modifications. Firstly, approximately $10^{6} \mathrm{CFU} / \mathrm{mL}$ of inoculum suspension was prepared and was used to dilute the tested compounds to obtain final concentrations of $0 \times \mathrm{MIC}$, $1 \times$ MIC, $2 \times$ MIC, and $4 \times$ MIC for each bacterial strain. Then, $10 \mu \mathrm{L}$ of each solution (a compound with inoculum suspension) at $0 \mathrm{~h}, 0.5 \mathrm{~h}, 1 \mathrm{~h}, 2 \mathrm{~h}$, and $4 \mathrm{~h}$ were serially diluted (10-6-10-2) with $1 \%$ of PBS and spread onto the MHA plates using a sterile cotton swab with replicates $(n=1 \times 2)$ and was incubated at $37^{\circ} \mathrm{C}$ overnight. After $24 \mathrm{~h}$, the number of colonies present on the plates were measured and recorded as CFU $/ \mathrm{mL}$ and a $\log _{10}$ $\mathrm{CFU} / \mathrm{mL}$ over time graph was plotted. The results obtained signifies bactericidal activity, whereby a reduction of $99.9 \%\left(\geq 3 \log _{10}\right)$ of the total number of $\mathrm{CFU} / \mathrm{mL}$ in the original inoculum was expected. The time-kill assay was carried out twice in triplicates $(n=2 \times 3)$.

\subsection{Molecular Docking Studies}

The crystallographic structure of Penicillin-Binding protein 2a (PBP2a) from MRSA ATCC700699 was retrieved from the Protein Data Bank (www.rcsb.org; PDB ID: 6Q9N. accessed on 25 February 2021). Molecular docking was performed to elucidate the possible binding interactions of the most active compounds (compounds 8, 9, and 10) to the standard drug, chlorhexidine (CHX) with the MRSA protein using AutoDockTools 1.5.4 (http:/ / mgltools.scripps.edu, accessed on 25 February 2021) and AutoDock Vina (http:/ / vina. scripps.edu, accessed on 25 February 2021) programs. The ligand and water molecules were removed, and hydrogen atoms were added to the $6 \mathrm{Q} 9 \mathrm{~N}$.pdb crystal structure before the docking analysis. The water molecules removal step was performed to ease the computations and to clear the binding site that can distort the search [10]. AutoDockTools 1.5.4 was used to add the missing hydrogen atoms for the formation of the hydrogen bond network leading to molecular docking [41]. The 3D structure of the most active inhibitors (compounds 8, 9, and 10) was built using Avagadro while the 3D structure of the standard drug, CHX was obtained from the PubChem website (https: / / pubchem.ncbi.nlm.nih.gov, accessed on 25 February 2021). These structures were geometrically optimized by energy minimization using the General AMBER Force Field (GAFF) potential function and were prepared by assigning the non-polar hydrogen using AutoDockTools 1.5.4. AutoDockTools 1.5.4 was used to generate the docking input files and to analyze the rigid docking results. Docking calculations were performed with an automated docking software, AutoDock 
Vina [42]. The final output obtained from the docking procedure is a set of conformations ranked correspondingly to their scoring function values. Meanwhile, Discovery Studio Visualizer 4.0 was used to visualize the interaction between enzymes and ligands in both $2 \mathrm{D}$ and $3 \mathrm{D}$ representations.

\subsection{Scanning Electronic Microscope Analysis}

Fresh methicillin-resistant S. aureus (MRSA) ATTC700699 and three clinical isolates $(172918,180620$, and 180865) of S. aureus bacteria were treated with compound 9 and incubated at $37^{\circ} \mathrm{C}$ in MHB for one hour. The pellets were collected by ALC microcentrifuge 4214 at $12,000 \times g$ for $10 \mathrm{~min}$ (ALC, Milan, Italy) and were fixed with $2.5 \%$ glutaraldehyde for $4-6 \mathrm{~h}$ at $4{ }^{\circ} \mathrm{C}$. Then, the pellets were washed with $0.1 \mathrm{M}$ sodium cacodylate buffer for 10 min thrice. Fixing of the pellets was performed using $1 \%$ osmium tetroxide for two hours at $4{ }^{\circ} \mathrm{C}$ and re-washed thrice with $0.1 \mathrm{M}$ sodium cacodylate buffer for $10 \mathrm{~min}$ each time. Following that, the pellets were dehydrated using 35, 50, 75, and 95\% acetone for 10 min each concentration. Finally, the pellets were dehydrated for $15 \mathrm{~min}$ using 100\% acetone, and this process was repeated three times. The cell suspension was transferred into an albumin-coated aluminium foil specimen basket and placed in a critical dryer for $30 \mathrm{~min}$. The specimen was then stacked on a stub and then sputter-coated with gold. Examination of the bacterial morphology was observed using a JEOL JSM 6400 scanning electron microscope (JEOL Ltd., Tokyo, Japan) and the images were captured.

\subsection{In Vivo Toxicity in Zebrafish Embryos}

\subsubsection{Zebrafish Husbandry and Embryo Collection}

The embryos were produced through natural mating of wild-type (WT) and transgenic $T g(k d r l: e g f p)$ adult zebrafish provided by the Zebrafish Center for Disease Modeling, Korea. The mated zebrafish were kept in a mixed male and female enclosure (ratio of 2:3), with $14 \mathrm{~h}$ of light: $10 \mathrm{~h}$ of darkness-controlled photoperiod within an ambient temperature of $28.5^{\circ} \mathrm{C}$. The embryos were collected $30 \mathrm{~min}$ after the onset of light, washed with distilled water, rinsed with embryo media $\left(15 \mathrm{mM} \mathrm{NaCl}, 0.5 \mathrm{mM} \mathrm{KCl}, 1 \mathrm{mM} \mathrm{MgSO}, 0.15 \mathrm{mM} \mathrm{KH}_{2} \mathrm{PO}_{4}\right.$, $0.05 \mathrm{mM} \mathrm{Na}_{2} \mathrm{HPO}_{4}, 1 \mathrm{mM} \mathrm{CaCl}_{2}, 0.7 \mathrm{mM} \mathrm{NaHCO}, \mathrm{pH} 7.0$ ), and incubated at $28{ }^{\circ} \mathrm{C}$. The unfertilized embryos were discarded to prevent fungal development. The fertilized embryos were examined and chosen under a standard dissection Leica S6E microscope (Leica, Wetzlar, Germany). All animal experiments were carried out in accordance with the approved guidelines and regulations of the Institutional Animal Care and Use Committee (IACUC) at Chungnam National University [43].

\subsubsection{Acute Toxicity Testing on Zebrafish Embryos}

To assess the acute toxicity on early embryonic growth, ten zebrafish embryos at $6 \mathrm{hpf}$ were inserted into each well of a 24 -well plate, containing $1 \mathrm{~mL}$ of embryo medium. Analogue 9 was firstly dissolved in DMSO to prepare a $40 \mathrm{mM}$ stock solution and further diluted with embryonic water at 10, 20, 40, 75, 150, 300, 600, and $1200 \mathrm{uM}$ concentrations. The compound solution was changed every day to keep the solutions fresh. To procure microscopic images, zebrafish embryos were dechorionated using forceps, anesthetized in Tricaine (Sigma-Aldrich, St. Louis, MO, USA), and placed in 3\% methylcellulose. Embryos were viewed via a Leica M205 FCA microscope (Leica, Wetzlar, Germany), while the digital images were captured using a Leica DFC450C digital camera (Leica) and processed with the Leica Application Suite (Leica, Wetzlar, Germany) [43].

\subsubsection{Evaluation of Abnormalities on the Formation of Blood Vessels}

Zebrafish embryos collected from the blood vessel-specific EGFP fluorescent transgenic zebrafish line, $\operatorname{Tg}(k d r l: e g f p)$, were either treated with $0.1 \%$ DMSO as a control or treated with different concentrations $(10,20$, and $40 \mu \mathrm{M})$ of compound 9 . The exposure to 9 commenced from the late gastrula stage at $10 \mathrm{hpf}$ and was examined at $30 \mathrm{hpf}$ when normal blood vessel formation was prominent in the control zebrafish. For bioimaging 
purposes, the assayed embryos were placed in 3\% methylcellulose on a glass slide and live animal images were taken by a CELENA ${ }^{\circledR}$ S Digital Imaging System (Logos Biosystems, Anyang, Korea) [43].

\subsubsection{Evaluation of Apoptosis}

The measurement of cell death in the wild-type zebrafish larvae after exposure to compound 9 was performed using the vital fluorescent dye acridine orange (AO) method, which is commonly used as a marker of apoptotic cells in zebrafish. AO staining is a rapid method that has been shown to be highly selective for apoptotic cells in zebrafish embryos. The live zebrafish larvae were firstly immersed in the egg water containing $4 \mu \mathrm{g} / \mathrm{mL}$ of AO (Sigma-Aldrich, St. Louis, MO, USA) for $20 \mathrm{~min}$, washed with the egg water five times for 5 min each, anesthetized with tricaine and mounted in 3\% methy examined by stereomicroscopy and fluorescent microscopy $[44,45]$.

\subsubsection{Statistical Analysis}

Statistical analyses were conducted using SPSS (SPSS v. 25.0). The effects of each treatment group over the control were determined based on a one-way analysis of variance (ANOVA). Data were represented as the mean \pm standard error mean using GraphPad Prism (GraphPad Software, Inc., San Diego, CA, USA), and were significantly different when $p \leq 0.05$. To ensure the generated values were independent, the analysed data were based on a per well basis to prevent any interaction biases among the embryos [42].

\section{Conclusions}

In conclusion, a series of non-PAINS related pyrrolylated-chalcone analogues (1-15) were successfully synthesized and tested for their potential as anti-MRSA agents in vitro. The results revealed that the hydroxyl-containing pyrrolylated-chalcones $(\mathbf{8}, \mathbf{9}$, and $\mathbf{1 0})$ exhibit remarkable MRSA inhibition. Furthermore, the time-kill curve plot shows that MRSA strains treated with compound 9 resulted in the death of all bacterial cells within four hours. The docking results revealed that ligand $\mathbf{9}$ showed similar bonding interactions to the standard drug, chlorhexidine (CHX) in the PBP2a active site, with their binding affinity scores of $-7.0 \mathrm{kcal} / \mathrm{mol}$ and $-8.2 \mathrm{kcal} / \mathrm{mol}$, respectively. Further validations with SEM highlight the bactericidal characteristic of compound 9 , as the evenly shaped S. aureus cells were turned into irregular shapes and were also partially disintegrated, post-treatment. In addition, no harmful effects were observed in the normal embryonic development, blood vessel formation, and apoptosis processes during a 24-h in vivo zebrafish model treatment with up to $40 \mu \mathrm{M}$ of compound 9 . Results of the study suggest that compound 9 (meta-hydroxy) is a promising compound for the inhibition of MRSA. Furthermore, all the collected data can be used as preliminary information for hit-to-lead optimization, enzyme-based in vitro efficiency measurement, in vivo efficacy, and safety assessment in bigger mammalian models and mechanisms of action to speed up the discovery of new antibiotics.

Supplementary Materials: The following are available online. Table S1: Spectrometric and general data of pyrrolylated-chalcone analogues (1-15), Table S2: The Lipinski rule values of pyrrolylatedchalcone analogues generated from FAF-Drugs4.

Author Contributions: Conceptualization, S.M.M.F. and Y.R.; methodology, M.G., S.M.M.F., Y.R., M.A.M.L. and C.-H.K.; NMR analysis, M.G. and T.K.; anti-MRSA analysis, M.G. and Y.R.; molecular docking analysis, M.G. and M.A.M.L.; experimental investigation, M.G. and T.-I.C.; resources, S.M.M.F., Y.R. and C.-H.K.; writing—original draft preparation, M.G.; writing—review and editing, S.M.M.F., Y.R., M.A.M.L. and C.-H.K.; supervision, S.M.M.F.; project administration, S.M.M.F.; funding acquisition, S.M.M.F. and C.-H.K. All authors have read and agreed to the published version of the manuscript. 
Funding: This research was funded by Putra grant-Putra Graduates Initiative (IPS) (Grant number GP-IPS /2018/9618500 to S.M.M.F.) and National Research Foundation (NRF) of Korea (Grant number 2018M3A9B8021980 to C.-H.K.).

Institutional Review Board Statement: All zebrafish experiments were carried out in accordance with the approved guidelines and regulations of the Institutional Animal Care and Use Committee (IACUC) at Chungnam National University (Approval number: CNU 00191).

Informed Consent Statement: Not applicable.

Data Availability Statement: Not applicable.

Acknowledgments: The authors would like to acknowledge Universiti Putra Malaysia and National Research Foundation (NRF) of Korea for their financial support.

Conflicts of Interest: The authors declare no conflict of interest.

Sample Availability: Not available.

\section{References}

1. Zaki, H.; Belhassan, A.; Aouidate, A.; Lakhlifi, T.; Benlyas, M.; Bouachrine, M. Antibacterial study of 3-(2-amino-6phenylpyrimidin-4-yl)- $N$-cyclopropyl-1-methyl- $1 H$-indole-2-carboxamide derivatives: CoMFA, CoMSIA analyses, molecular docking and ADMET properties prediction. J. Mol. Struct. 2019, 1177, 275-285. [CrossRef]

2. MacVane, S.H. Antimicrobial resistance in the intensive care unit: A focus on gram-negative bacterial infections. J. Intensive Care Med. 2017, 32, 25-37. [CrossRef]

3. Prabhoo, R.; Chaddha, R.; Iyer, R.; Mehra, A.; Ahdal, J.; Jain, R. Overview of methicillin resistant Staphylococcus aureus mediated bone and joint infections in India. Orthop Rev. 2019, 11, 8070-8075. [CrossRef]

4. Shamsuddin, N.A.M.; Basri, D.F. Anti-methicillin resistant Staphylococcus aureus (MRSA) activity of an acetone extract from the leaves of Canarium odontophyllum (Miq.). J. Phytopharmacol. 2018, 7, 225-229.

5. Negi, B.; Kumar, D.; Kumbukgolla, W.; Jayaweera, S.; Ponnan, P.; Singh, R.; Rawat, D.S. Anti-methicillin resistant Staphylococcus aureus activity, synergism with oxacillin and molecular docking studies of metronidazole-triazole hybrids. Eur. J. Med. Chem. 2016, 115, 426-437. [CrossRef] [PubMed]

6. Sivakumar, P.M.; Ganesan, S.; Veluchamy, P.; Doble, M. Novel chalcones and 1,3,5-triphenyl-2-pyrazoline derivatives as antibacterial agents. Chem. Biol. Drug Des. 2010, 76, 407-411. [CrossRef]

7. Attarde, M.; Vora, A.; Varghese, A.; Kachwala, Y. Synthesis and evaluation of chalcone derivatives for its alpha amylase inhibitory activity. Org. Chem. An. Indian J. 2014, 10, 192-204.

8. Özdemir, A.; Altıntop, M.D.; Sever, B.; Gençer, H.K.; Kapkaç, H.A.; Atlı, Ö.; Baysal, M. A new series of pyrrole-based chalcones: Synthesis and evaluation of antimicrobial activity, cytotoxicity, and genotoxicity. Molecules 2017, 22, 2112. [CrossRef]

9. Mohd Faudzi, S.M.; Abdullah, M.A.; Manap, M.R.A.; Ismail, A.Z.; Rullah, K.; Mohd Aluwi, M.F.F.; Ramli, A.N.M.; Abas, F.; Lajis, N.H. Inhibition of nitric oxide and prostaglandin E2 production by pyrrolylated-chalcones: Synthesis, biological activity, crystal structure analysis, and molecular docking studies. Bioorg. Chem. 2020, 94, 103376-103393. [CrossRef]

10. Peters, E.A.H. Synthesis of Oxadeazoles with Electron Withdrawing Groups and the Analysis of Product Yield with Bond Length. Bachelor's Thesis, Otterbein University, Westerville, OH, USA, 2017.

11. Williams, I.S.; Joshi, P.; Gatchie, L.; Sharma, M.; Satti, N.K.; Vishwakarma, R.A.; Bharate, S.B. Synthesis and biological evaluation of pyrrole-based chalcones as CYP1 enzyme inhibitors, for possible prevention of cancer and overcoming cisplatin resistance. Bioorg. Med. Chem. Lett. 2017, 27, 3683-3687. [CrossRef]

12. Diaz-Uribe, C.E.; Vallejo, W.; Castellar, W.; Trilleras, J.; Ortiz, S.; Rodriguez-Serrano, A.; Quiroga, J. Novel (E)-1-(pyrrole-2-yl)-3(aryl)-2-(propen-1-one) derivatives as efficient singlet oxygen quenchers: Kinetics and quantum chemical calculations. RSC Adv. 2015, 5, 71565-71572. [CrossRef]

13. Sharma, P.; Kumar, S.; Ali, F.; Anthal, S.; Gupta, V.K.; Khan, I.A.; Satti, N.K. Synthesis and biologic activities of some novel heterocyclic chalcone derivatives. Med. Chem. Res. 2013, 22, 3969-3983. [CrossRef]

14. Budhiraja, A.; Kadian, K.; Kaur, M.; Aggarwal, V.; Garg, A.; Sapra, S.; Dhar, K.L. Synthesis and biological evaluation of naphthalene, furan and pyrrole based chalcones as cytotoxic and antimicrobial agents. Med. Chem. Res. 2012, 21, 2133-2140. [CrossRef]

15. Genuit, T.; Bochicchio, G.; Napolitano, L.M.; McCarter, R.J.; Roghman, M.C. Prophylactic chlorhexidine oral rinse decreases ventilator-associated pneumonia in surgical ICU patients. Surg. Infect. 2001, 2, 5-18. [CrossRef]

16. Stompor, M.; Żarowska, B. Antimicrobial activity of xanthohumol and its selected structural analogues. Molecules 2016, 21, 608. [CrossRef]

17. Xu, M.; Wu, P.; Shen, F.; Ji, J.; Rakesh, K.P. Chalcone derivatives and their antibacterial activities: Current development. Bioorg. Chem. 2019, 91, 103-133. [CrossRef]

18. Kozlowska, J.; Potaniec, B.; Baczynska, D.; Zarowska, B.; Aniol, M. Synthesis and biological evaluation of novel aminochalcones as potential anticancer and antimicrobial agents. Molecules 2019, 24, 4129. [CrossRef] 
19. Ma, L.; Yang, Z.; Li, C.; Zhu, Z.; Shen, X.; Hu, L. Design, synthesis and SAR study of hydroxychalcone inhibitors of human $\beta$-secretase (BACE1). J. Enzym. Inhibit. Med. Chem. 2011, 26, 643-648. [CrossRef]

20. Gillis, E.P.; Eastman, K.J.; Hill, M.D.; Donnelly, D.J.; Meanwell, N.A. Applications of fluorine in medicinal chemistry. J. Med. Chem. 2015, 58, 8315-8359. [CrossRef] [PubMed]

21. Ramli, S.; Radu, S.; Shaari, K.; Rukayadi, Y. Antibacterial activity of ethanolic extract of Syzygium polyanthum L. (Salam) leaves against foodborne pathogens and application as food sanitizer. Biomed. Res. Int. 2017, 2017, 9024246-9024258. [CrossRef]

22. Balouiri, M.; Sadiki, M.; Ibnsouda, S.K. Methods for in vitro evaluating antimicrobial activity: A review. J. Pharm. Anal. 2016, 6, 71-79. [CrossRef]

23. Pankey, G.A.; Ashcraft, D.S. In vitro antibacterial activity of tigecycline against resistant Gram-negative bacilli and enterococci by time-kill assay. Diagn. Microbiol. Infect. Dis. 2009, 64, 300-304. [CrossRef] [PubMed]

24. Clinical and Laboratory Standards Institute (CLSI). Methods for Determining Bactericidal Activity of Antimicrobial Agents; Approve, Guideline; Barry, A.L., Craig, W.A., Nadler, H., Reller, L.B., Sanders, C.C., Swenson, J.M., Eds.; National Committee for Clinical Laboratory Standards document M26-A: Villanova, PA, USA, 1999.

25. Akbar, A.; Sadiq, M.B.; Ali, I.; Muhammad, N.; Rehman, Z.; Khan, M.N.; Anal, A.K. Synthesis and antimicrobial activity of zinc oxide nanoparticles against foodborne pathogens Salmonella typhimurium and Staphylococcus aureus. Biocatal. Agric. Biotechnol. 2019, 17, 36-42. [CrossRef]

26. Janardhanan, J.; Bouley, R.; Martínez-Caballero, S.; Peng, Z.; Batuecas-Mordillo, M.; Meisel, J.E.; Chang, M. The quinazolinone allosteric inhibitor of PBP2a synergizes with piperacillin and tazobactam against methicillin-resistant Staphylococcus aureus. Antimicrob. Agents Chemother. 2019, 63, e02637-18. [CrossRef]

27. Dong, L.; Shen, S.; Chen, W.; Xu, D.; Yang, Q.; Lu, H.; Zhang, J. Discovery of novel inhibitors targeting human O-GlcNAcase: Docking-based virtual screening, biological evaluation, structural modification, and molecular dynamics simulation. J. Chem. Inf. Model. 2019, 59, 4374-4382. [CrossRef]

28. Mizgirev, I.V.; Revskoy, S. A new zebrafish model for experimental leukemia therapy. Cancer Biol. Ther. 2010, 9, 895-902. [CrossRef]

29. Han, H.S.; Jang, G.H.; Jun, I.; Seo, H.; Park, J.; Glyn-Jones, S.; Edwards, J.R. Transgenic zebrafish model for quantification and visualization of tissue toxicity caused by alloying elements in newly developed biodegradable metal. Sci. Rep. 2018, 8 , 13818-13826.

30. Ryan, R.; Moyse, B.R.; Richardson, R.J. Zebrafish cardiac regeneration-Looking beyond cardiomyocytes to a complex microenvironment. Histochem. Cell Biol. 2020, 154, 533-548. [CrossRef]

31. Garcia, G.R.; Noyes, P.D.; Tanguay, R.L. Advancements in zebrafish applications for 21st century toxicology. Pharmacol. Ther. 2016, 161, 11-21. [CrossRef]

32. Hermsen, S.A.; van den Brandhof, E.J.; van der Ven, L.T.; Piersma, A.H. Relative embryotoxicity of two classes of chemicals in a modified zebrafish embryotoxicity test and comparison with their in vivo potencies. Toxicol. In Vitro 2011, 25, 745-753. [CrossRef] [PubMed]

33. Jayasinghe, C.D.; Jayawardena, U.A. Toxicity assessment of herbal medicine using zebrafish embryos: A systematic review. Evid. Based Complement. Altern. Med. 2019, 2019, 7272808-7272825. [CrossRef]

34. Lammer, E.; Carr, G.J.; Wendler, K.; Rawlings, J.M.; Belanger, S.E.; Braunbeck, T. Is the fish embryo toxicity test (FET) with the zebrafish (Danio rerio) a potential alternative for the fish acute toxicity test? Comp. Biochem. Physiol. C Toxicol. Pharmacol. 2009, 149, 196-209. [CrossRef]

35. Bailey, J.; Oliveri, A.; Levin, E.D. Zebrafish model systems for developmental neurobehavioral toxicology. Birth Defects Res. C Embryo Today 2013, 99, 14-23. [CrossRef]

36. Wei, Y.; Li, P.; Wang, C.; Peng, Y.; Shu, L.; Jia, X.; Wang, B. Metabolism of tanshinone IIA, cryptotanshinone and tanshinone I from Radix Salvia miltiorrhiza in zebrafish. Molecules 2012, 17, 8617-8632. [CrossRef] [PubMed]

37. Cole, L.K.; Ross, L.S. Apoptosis in the developing zebrafish embryo. Dev. Biol. 2001, 240, 123-142. [CrossRef]

38. Lagorce, D.; Bouslama, L.; Becot, J.; Miteva, M.A.; Villoutreix, B.O. FAF-Drugs4: Free ADME-tox filtering computations for chemical biology and early stages drug discovery. Bioinformatics 2017, 33, 3658-3660. [CrossRef]

39. Clinical and Laboratory Standards Institute (CLSI). Methods for Dilution Antimicrobial Susceptibility Tests for Bacteria That Grow Aerobically; Weinstein, M.P., Patel, J.B., Burnham, C., Campeau, S., Conville, P.S., Doern, C., Eliopoulus, G.M., Galas, M.F., Humphries, R.M., Jenkins, S.G., Eds.; National Committee for Clinical Laboratory Standards document M07: Wayne, PA, USA, 2012.

40. Rukayadi, Y.; Shim, J.S.; Hwang, J.K. Screening of Thai medicinal plants for anticandidal activity. Mycoses 2008, 51, 308-312. [CrossRef] [PubMed]

41. Patil, R.; Das, S.; Stanley, A.; Yadav, L.; Sudhakar, A.; Varma, A.K. Optimized hydrophobic interactions and hydrogen bonding at the target-ligand interface leads the pathways of drug-designing. PLoS ONE 2010, 5, e12029. [CrossRef]

42. Hernández-Santoyo, A.; Tenorio-Barajas, A.Y.; Altuzar, V.; Vivanco-Cid, H.; Mendoza-Barrera, C. Protein-protein and proteinligand docking. In Protein Engineering-Technology and Application; Ogawa, T., Ed.; IntechOpen: London, UK, 2013 ; pp. 63-81. 
43. Abdullah, M.A.; Lee, Y.R.; Mastuki, S.N.; Leong, S.W.; Wan Ibrahim, W.N.; Mohammad Latif, M.A.; Ramli, A.N.M.; Mohd Aluwi, M.F.F.; Mohd Faudzi, S.M.; Kim, C.H. Development of diarylpentadienone analogues as alpha-glucosidase inhibitor: Synthesis, in vitro biological and in vivo toxicity evaluations, and molecular docking analysis. Bioorg. Chem. 2020, 104, 104277-104291. [CrossRef] [PubMed]

44. Jeong, Y.M.; Jin, T.E.; Choi, J.H.; Lee, M.S.; Kim, H.T.; Hwang, K.S.; Kim, C.H. Induction of clusterin expression by neuronal cell death in Zebrafish. J. Genet. Genom. 2014, 41, 583-589. [CrossRef]

45. Kim, H.T.; So, J.H.; Jung, S.H.; Ahn, D.G.; Koh, W.; Kim, N.S.; Kim, C.H. Cug2 is essential for normal mitotic control and CNS development in zebrafish. BMC Dev. Biol. 2011, 11, 49-56. [CrossRef] [PubMed] 